\title{
Representational Standing: U.S. ex rel. Stevens and the Future of Public Law Litigation
}

\author{
Myriam E. Gilles†
}

\section{INTRODUCTION}

The Supreme Court's constitutionalization of standing doctrine $e^{1}$ over the past three decades has drawn widespread and impassioned attention. By locating rules defining standing within the Constitution, the Court has placed unprecedented limitations upon federal legislators who might otherwise wish to vest private individuals with broad standing to enforce various laws. ${ }^{2}$ In an era where politicians are confronted with demands to shrink the size of government and to draw upon "public-private partnerships" to solve problems in areas ranging from inner-city housing to the environment, the constitutional rules of standing loom large as an impediment to any legislative effort to tap private resources in the enforceinent of public laws.

Copyright $@ 2001$ California Law Review, Inc. California Law Review, Inc. (CLR) is a California nonprofit corporation. CLR and the authors are solely responsible for the content of their publications.

$\dagger$ Assistant Professor of Law, Benjamin N. Cardozo School of Law, Yeshiva University. B.A., Harvard-Radcliffe Colleges, 1993; J.D., Yale Law School, 1996. l'd like to thank Gary Friedman, David Gray Carlson, Michael Herz, Melanie Leslie, John Parry, Peter Schuck, and Stewart Sterk for their helpful comments on an earlier draft. I am also grateful for the summer stipend provided by Cardozo Law School. Katherine Richardson provided helpful researcl assistance.

1. The phrase "constitutionalization of standing doctrine" is used throughout this Article to refer to the Supreme Court's use of the standing doctrine to restrict the ability of private citizens to vindicate broad public rights and limit the authority of Congress to vest such power in the citizenry. Specifically, I argue here that, over the past three decades, the Court has increasingly viewed standing as grounded in Article III of the Constitution and separation of powers doctrine. This "constitutionalization" process thus stands in stark contrast to prior Courts, which viewed standing doctrine as comprised of prudential, subconstitutional concerns regarding judicial self-governance and the presentation of issues in an adversarial context. Infra Part I.

2. As I have argued in a related context, the landmark constitutional cases of the last century, such as Brown v. Board of Education, 349 U.S. 294 (1955), Roe v. Wade, 410 U.S. 113 (1973), Regents of the University of California v. Bakke, 438 U.S. 265 (1978), were driven by private plaintiffs who sought not only redress for the harms that they had personally suffered, but also protection for society at large agamst those harms. The Court's constitutionalized standing doctrine has effectively neutered the popular force that powered these refornative enterprises. Myriam E. Gilles, Reinventing Structural Reform Litigation: Deputizing Private Citizens in the Enforcement of Civil Rights, 100 Colum. L. REv. 1384, 1386-88 (2000). 
The Supreme Court's May 2000 decision in Vermont Agency of Natural Resources $v$. United States ex rel. Stevens ${ }^{3}$ marks a radical reconfiguration of the landscape facing legislators seeking to vest private actors with standing to enforce federal laws. In an opinion authored by Justice Scalia, the chief architect of the Court's constitutionalized standing jurisprudence, the Court has effectively provided legislators with a constitutional road map for vesting standing im persons who would not otherwise satisfy the demanding Article III requireinents.

In particular, the Court in Stevens endorsed a theory of "representational standing," whereby the United States may, under certain circumstances, confer its standing to enforce federal laws upon a private actor as the "agent" or "assignee" of the government and its claims. ${ }^{4}$ By carefully considering the emerging doctrine of representational standing, Congress is now free to bring private resources to bear in the enforcement of environmental, civil rights, consumer protection and other statutes. This Article aims to unpack the theories of representational standing suggested in Stevens and to explore their potential for resuscitating public law litigation, the engine which powered the great social reforn movements of the 1950s and 1960s, and which has lain dormant in the wake of the Court's constitutionalized standing jurisprudence.

Part I reviews the Supreme Court's modern standing jurisprudence, giving particular attention to the constitutionalization of standing doctrine and the limits iniposed upon congressional efforts to broaden the class of private citizens who may bring suit to vindicate public interests. Part II introduces the Stevens case and discusses the bases of the Court's ruling on standing. Part III analyzes the theory of representational standing and attempts to discern the rules that will govern congressional attempts to vest private citizens with standing as agents or assignees of the government. Part IV considers potential applications of the Court's newly minted representational standing theory and reflects upon the implications of this theory for the future of public law litigation.

\section{I}

\section{The Evolution of Standing Doctrine}

Standing is a doctrine of justiciability by which federal courts determine whether a particular "case"s or "controversy" is appropriate for

3. 120 S. Ct. $1858(2000)$.

4. Id. at $1862-63$.

5. U.S. ConsT. art. III, $\S 2$ ("The judicial Power shall extend to all cases ... arising under this Constitution, the Law of the United States, and Treaties made, or which shall be made, under their Authority; to all Cases affecting Ambassadors, other public Ministers and Consuls; to all Cases of admiralty and maritime Jurisdiction .....").

6. Id. ("The judicial Power shall extend to ... Controversies to which the United States shall be a Party; to Controversies between two or more States; between a State and Citizens of another State; 
federal adjudication. Unlike the other justiciability doctrines, ${ }^{7}$ standing concentrates on the status of the litigants rather than the issues in dispute, ${ }^{8}$ and asks whether an individual plaintiff has a sufficient stake in the outcome of a matter to justify his right to litigate the issue in federal court. ${ }^{9}$

Over the past three decades, the Supreme Court has used standing doctrine to restrict the ability of private citizens to vindicate broad public rights and, concomitantly, to limit the authority of Congress to vest such power in the citizenry. ${ }^{10}$ In denying standing to individuals or groups of citizens seeking to remedy environmental wrongs, ${ }_{11}^{11}$ racial discrimination, ${ }^{12}$ police brutality, ${ }^{13}$ and First Amendment violations, ${ }^{14}$ the Court has grounded its standing rules squarely within Article III of the Constitution. ${ }^{15}$

between Citizens of different States; between Citizens of the same State claiming Lands under the Grants of different States, and between a State, or the Citizens thereof, and foreign States, Citizens or Subjects.").

7. The other justiciability doctrines prohibit advisory opinions, collusive suits, and determinations of political questions. In addition, the justiciability doctrines of ripeness and mootness seek to ensure that cases or controversies are appropriate for judicial review. See, e.g., $13 \mathrm{C}$. WRIGHT et al., Federal Practice and Procedure \$ 3529, at 146 (1975); see also Asliwander v. Tenn. Valley Auth., 297 U.S. 288, 346-48 (1936) (Brandeis, J., concurring).

8. See, e.g., Flast v. Colien, 392 U.S. 83, 99-100 (1968) (finding that "when standing is placed in issue in a case, the question is whether the person wlose standing is challenged is a proper party to request an adjudication of a particular issue and not whether the issue itself is justiciable").

9. See ERIVIN CHEMERINSKY, Federal JuRISDiction 15 (3d ed. 1999) (noting that, through the doctrine of standing, federal courts ask the question "What's it to you?").

10. For an altemative (though related) telling of the tale, see Cass R. Sunsten, What's Standing After Lujan? Of Citizen Suits, "Injuries," and Article III, 91 MicH. L. REv. 163, 170-97 (1992) (discussing the five stages of standing lav and the political policies infiuencing the developinent of standing jurisprudence). Professor Sunstein's explanation of the evolution of standing law operates from the perspective of the growth of administrative agencies. For example, Professor Sunstein explains that Congress passed the Administrative Procedure Act to allow people "to have causes of action, and hence standing, even if their interests were not entitled to consideration by the relevant agency." Id. at 182 . During the 1960s and 1970s, courts allowed many people affected by govemment actions, regulatory beneficiaries, to file suit to bring agencies into conformity with law. See id. at 183 . Sunstein then posits that the contemporary law of standing refiects a judicial reluctance to supervise agency inaction based upon separation of powers concerns. Id. at 196-97.

11. See, e.g., Steel Co. v. Citizens for a Better Env't, 523 U.S. 83 (1998) (denying standing to citizen suit plaintiffs seeking to enjoin alleged violations of federal environmental statute); Lujan v. Defenders of Wildlife, 504 U.S. 555 (1992) (same).

12. See, e.g., Allen v. Wright, 468 U.S. 737, 760 (1984) (denying standing to parents of AfricanAmerican public school students who alleged that the tax-exenıpt status granted to private schools resulted in race discrimination; the Court reiterated that a "federal court . . . is not the proper forum to press general contplaints about the way in whicl government goes about its business" (quoting City of Los Angeles v. Lyons, 461 U.S. 95, $111-12$ (1983))).

13. See, e.g., City of Los Angeles v. Lyons, 461 U.S. 95 (1983) (denying standing to victim of police chokehold who sought equitable relief against future use of the chokehold by police officers in non-deadly threat situations).

14. See, e.g., Valley Forge Christian Coll. v. Americans United for Separation of Church \& State, Inc., 454 U.S. 464, 473 (1982) (holding that plaintiffs challenging government conveyance of property to religious college lacked standing because they were unable to show "injury in fact").

15. Justice Scalia, for example, has argued that "the judicial doctrine of standing is a crucial and inseparable element of [separation of powers], whose disregard will inevitably produce-as it has during the past few decades-an overjudicialization of the processes of self governance." Antonin 
In the process, the Court has promulgated detailed rules and multi-pronged tests designed to evaluate plaintiffs' standing to sue in light of the separation of powers interests embodied in the "case or controversy" requirement, as discussed below. ${ }^{16}$

By contrast, prior to the 1970 s, the Court resisted the view that the standing requirement implicated separation of powers concerns. Instead, the Court analyzed standing on a case-by-case basis, applying flexible and decidedly sub-constitutional standards. ${ }^{17}$ Under this approach, Congress's power to vest standing in whomever it deemed appropriate was simply beyond question. As a result, Congress has been able to vest standing in persons whom the Court had previously found to lack standing to sue, as those judicial decisions were not founded upon constitutional rules. ${ }^{18}$

Scalia, The Doctrine of Standing as an Essential Element of the Separation of Powers, 17 SUFFoLK U. L. REv. 881, 881 (1983). Other modern jurists have agreed; for example, Judge Robert Bork stated: "the entire concept of Article III standing rests on separation of powers." Haitian Refugee Ctr. v. Gracey, 809 F.2d 794, 804 (D.C. Cir. 1987); see also William A. Fletcher, The Structure of Standing, 98 YALE L.J. 221, 233 (1988) ("In significant part, a debate over what constitutes 'injury in fact" sufficient for Article III is thus a debate about separation of powers and the respective responsibilities of Congress and the Court.").

16. Separation of powers is the fundamental concept of a tripartite system of shared power among the branches of government. See, e.g., Lujan v. Defenders of Wildife, 504 U.S. 555, 557 (1992) (noting that while separation of powers is not an explicit constitutional requirement, it is a function of the Constitution's basic structure, which "divides all power conferred upon the Federal Government into 'legislative Powers,' '[t]he executive Power,' and '[ $t]$ he judicial Power") (intemal citations ounitted); Immigration \& Naturalization Serv. v. Chadha, 462 U.S. 919, 946 (1983) ("The very structure of the articles delegating and separating powers under Arts. I, II, and III exemplify the concept of separation of powers.").

17. In particular, prior Courts applied sub-constitutional "prudential" limitations on standing, which rested on "concern[s] about the proper-and properly limited-role of the courts in a democratic society," rather than constitutional interpretation. Warth v. Seldin, 422 U.S. 490, 498 (1975). These prudential limits include prohibitions against (1) raising a third party's legal rights, (2) pressing generalized grievances that one should address to the legislative or executive branch, and (3) litigating an issue that falls outside the "zone of interests" protected by the law in question. See Valley Forge Christian Coll., 454 U.S. at 474-75.

While much has been written about the admittedly fuzzy line between "prudential" standards and "constitutional" rules governing standing, see, c.g., Marla Mansfield, Standing and Ripeness Revisited: The Supreme Court's "Hypothetical" Barriers, 68 N.D. L. REv. 1, 66 (1992), it is clear that judge-made prudential limitations on standing allow courts to engage in self-governance and selfrestraint. See Lujan, 504 U.S. at 560 (characterizing prudential limitations on standing as "part of judicial self-government"). Prudential standing limitations embody "self-imposed restraints on the exercise of judicial power," United States Parole Comm'n v. Geraghty, 445 U.S. 388, 410 (1980), the content of which is "shaped by the decisions of the courts as a matter of sound judicial policy." Asarco Inc. v. Kadisl, 490 U.S. 605, 613 (1989). Thus, prudential limitations on standing tend to be flexible standards based on policy and fairness rather than rigid rules of constitutional construction based on separation of powers.

18. See, e.g., Fed. Election Comm'n v. Akins, 524 U.S. 11 (1998) (finding that Congress had eliminated prudential standing limitations in a category of cases); Raines v. Byrd, 521 U.S. 811, 811, 820 n.3 (1997) (noting that Congress possesses power to "eliminate any prudential standing limitations" on federal courts' exercise of the judicial power, simply by creating a cause of action); Bennett v. Spear, 520 U.S. 154, 162 (1997) (concluding unanimously that Congress had eliminated prudential standing limitations in the citizen-suit provisions of the Endangered Species Act, and stating explicitly that prudential standing limitations "can be modified or abrogated by Congress"). 
The shift in the law of standing from flexible normative standards to hard and fast rules anchored in separation of powers doctrine ${ }^{19}$ has thus raised significant questions over the limits of Congress's authority to vest individuals with standing to bring suit to vindicate broad public rights. ${ }^{20}$

\section{A. The Warren Court: Baker, Flast, and Prudential Limitations on Standing}

While the Supreme Court addressed the issue of standing sporadically in its decisions prior to the $1950 \mathrm{~s}$ and $1960 \mathrm{~s}^{21}$ the standing question came to prominence during the tenure of Chief Justice Earl Warren. ${ }^{22}$ During this period, the Court employed "an amalgam of standing presumptions drawn

19. See Patricia M. Wald, Environmental Postcards from the Edge: The Year That Was and the Year That Might Be, 26 ENVTL. L. REP. 10182, 10184 (1996) (noting a transformation in the early 1990 s, Judge Wald stated that "in my own court-encouraged in large part by the Supreme Court-we saw a retreat from the more generous notions of standing in the 1970's to one that increasingly required highly individualized and particularized allegations of imminent or existent injury that action of the court can substantially rectify").

20. See Bennett, 520 U.S. at 162 ("[T] hese "judicially self-imposed limits [prudential standing rules] on the cxercise of federal jurisdiction'. . . are 'founded in concern about the proper-and properly limited-role of the courts in a democratic society,'. . . but unlike their constitutional counterparts, they can be modified or abrogated by Congress ...." (citations omitted)).

21. Frothingham v. Mellon, 262 U.S. 447 (1923), was perhaps the most famous "standing" case of the early twentieth century. There, the Supreme Court denied standing to citizens seeking to challenge an increase in taxes. The Frothingham Court characterized the federal taxpayer's interest as a generalized one: "minute," "indeterminable," and "so remote, fluctuating and uncertain, that no basis is afforded for an appeal to the preventive powers of a court of equity." Id. at 487 . However, even this early formulation of standing was not firmly grounded in constitutional norms. While finding that the question of additional taxation was "essentially a matter of public and not of individual concern," the Court vaguely couched the question of standing as whether a legal question had "assume[d] such a form that the judicial power is capable of acting on it." Id.

Prior to Frothingham, the Court had reached the merits on at least four cases brought by taxpayers in their capacity as taxpayers. See Hawke v. Smith, 253 U.S. 221, 227 (1920) (challenging the printing of federal ballots for the referendum on the ratification of the eighteenth amendinent); Wilson v. Shaw, 204 U.S. 24, 31 (1907) (granting injunction against unconstitutional payments for the completion of the Panama Canal); Millard v. Roberts, 202 U.S. 429, 438 (1906) (challenging District of Columbia expenditures for private railroad improvements); Bradfield v. Roberts, 175 U.S. 291, 295 (1899) (enjoining, as a violation of the Establishment Clause, federal payments pursuant to a contract with a District of Columbia hospital run by Catholic nuns).

The briefs in these cases underscore the degree to which the questions of "standing" in the early twentieth century were seen as nonconstitutional. In Wilson, for example, the government argued that "a private citizen has not the necessary interest in the subject-matter of the controversy" and urged the Court to find that a plaintiff must show "some direct and personal injury to himself above that suffered by others." Brief for the Umited States at 2 , Wilson, (No. 43). The plaintiff, in response, relied on the shareholder model as support: "Private citizens under such circumstances occupy exactly the position of stockholders in private corporations." Brief for Appellant at 6, Wilson, (No. 43). The Court declined to rule on the sufficiency of Mr. Wilson's interest in maintaining the suit, instead ruling against him on the basis of familiar equity doctrines. It observed that the plaintiff's interest was insufficient to justify the issuance of an mjunction to stop work on the Panama Canal, given the balance of hardships. Wilson, 204 U.S. at 31.

22. See The Oxford Companion to the Supreme Court of the United States 48 (Kermit L. Hall et al. eds., 1992) (contrasting the Warren Court's liberal interpretation of the standing doctrine with the Burger and Rehnquist Courts' conservative applications). 
from the common law of property, contract, or tort," developed into "prudential standards,"24 to determine whether a litigant had standing to sue. ${ }^{25}$

For example, in Baker v. Carr, ${ }^{26}$ the Court articulated a "good fight" standard for determining whether a group of voters had standing to lodge a Fourteenth Amendinent challenge to voter redistricting: an individual must plead "such a personal stake in the outcome of the controversy as to assure that concrete adverseness which sharpens the presentation of issues upon which the Court so largely depends for illumination of difficult constitutional questions." 27 Finding that the voters had such a "deeply personal stake," the Baker Court granted standing. In doing so, the Court rejected the argument that the grant of standing to citizens whose alleged injury was undifferentiated from that of the public at large violated separation of powers, finding instead that the assurance of a good adversarial presentation was a sufficient basis for standing to sue. ${ }^{28}$ The Baker Court thus viewed Article III standing not as a protector of separation of powers, but instead as a means of ensuring that federal courts resolved only those issues presented in a clear, adversarial context.

Six years later, in Flast $v$. Cohen, ${ }^{29}$ seven taxpayers filed suit to challenge legislation which authorized the use of federal funds for instruction and materials for religious schools as violative of the Establishment Clause. The plaintiffs claimed that they had standing to challenge this legislation based on their status as taxpayers, even though the Supreme Court had previously held in Frothingham that a taxpayer lacked standing to challenge the constitutionality of a federal statute..$^{30}$ Despite the Frothingham decision, the Court created an exception to uphold taxpayer standing in the Flast case. The Flast Court held that a taxpayer has standing to challenge a particular exercise of the congressional taxing and spending power under a specific constitutional provision, such as the Establishment Clause, reasoning that the "logical nexus" between

23. Maxwell L. Steams, Standing and Social Choice: Historical Evidence, 144 U. PA. L. REv. 309, 394 (1995).

24. See supra text accompanying notes 17-20 (discussing prudential limitations on standing).

25. See, e.g., Mansfield, supra note 17 , at 66 .

26. 369 U.S. 186 (1962) (permitting voters to challenge legislative districting on the ground that disparities in the number of voters violate their rights to equal protection).

27. Id. at 204. Chief Justice Warren considered Baker to be the most important achievement in his fifteen years on the Court. The Oxford Companion to the Supreme Court of the United STATES, supra note 22 , at 17.

28. Baker, 369 U.S. at 199; see also Kenneth M. Casebeer, The Empty State and Nobody's Market: The Political Economy of Non-Responsibility and the Judicial Disappearing of the Civil Rights Movement, 54 U. Miami L. Rev. 247, $278-79$ (2000).

29. 392 U.S. 83 (1968) (granting standing to federal taxpayers to challenge government aid to religious schools on Establishment Clause grounds).

30. Frothingham v. Mellon, 262 U.S. 447 (1923). 
the taxpayer's status and the challenged legislation assured sufficiently meaningful presentation of the issues to warrant adjudication. ${ }^{31}$

Writing for an eight-to-one Flast majority, ${ }^{32}$ Chief Justice Warren again rejected the government's separation of powers argument, finding that "the question whether a particular person is a proper party to maintain the action does not, by its own force, raise [constitutional] separation of powers problems related to improper judicial interference in areas committed to the other branches of the Federal Government." ${ }^{33}$ Rather, the Flast majority found that, to establish standing for judicial review, a plaintiff must demonstrate "a sufficient stake in an otherwise justiciable controversy to obtain judicial resolution of that controversy" and "a logical nexus between the status asserted and the claim sought to be adjudicated."34

Both Baker and Flast demonstrate the Warren Court's reliance on prudential doctrines to determine standing questions. While acknowledging the constitutional backdrop in both cases, ${ }^{35}$ the Court rejected separation of powers as an element of the standing determination. Instead, it determined that the core purpose of the standing doctrine was to help "limit the business of federal courts to questions presented in an adversary context and in a form historically viewed as capable of resolution through the judicial process." ${ }^{36}$ The citizens in Baker and the taxpayers in Flast had both, in "an adversary context," alleged injuries that were "capable of resolution through the judicial process." Thus, the Court granted them access to the federal courts, notwithstanding the generalized nature of their grievances or the possibility that the political process might well remedy their injuries.

The liberal views of standing developed under the Warren Court were perhaps part of a larger picture in which "schools were ordered desegregated, the Bill of Rights was made enforceable against the states, First Amendinent guarantees were bolstered, a right to privacy was 'discovered,' criminal procedure protections were strengthened, and

31. Flast, 392 U.S. at 103 . Justice Stewart and Justice Fortas wrote concurring opinions in which they interpreted the Court's decision as only holding that taxpayers had standing to challenge federal expenditures that allegedly violated the Establishment Clause. See id. at 114-15.

32. Justice Harlan dissented in Flast. See id. at 116-33.

33. Id. at 100 .

34. Id. at 102. Professor Tribe observed that in Flast, the Warren Court opined that standing was premised on the principle of ensuring adverseness, rather than upon concerns with potential separation of powers issues. LaUREnce H. Tribe, American Constitutional Law \$ 3-14, at 108-09 (2d ed. 1988); see also Flast, 392 U.S. at 100-01 (stating that when separation of powers issues arise, they coine froin the substantive issues the plaintiffs seek to adjudicate rather than the threshold issue of justiciability, of which standing is but one inquiry).

35. Flast, 392 U.S. at 94 (noting that standing helps to "define the role assigned to the judiciary in a tripartite allocation of power to assure that the federal courts will not intrude into areas committed to the other branches of government").

36. Id. 
orchestrated school prayer was made illegal." 937 The recognition of these substantive rights required procedural safeguards to "ensure that the guarantee of those rights would be actually realized." 38 The flexible standards used to determine standing questions during this era may be properly viewed as part of the Warren Court's installation of procedural mechanisms for the protection of substantive rights. ${ }^{39}$

Thus, through the late $1960 \mathrm{~s}$, the Court viewed the standing doctrine as a tool desigued to improve judicial decision making and conserve judicial resources by narrowing issues. ${ }^{40}$ In a word, the doctrine was a prudential one; rarely, if ever, was the Constitution invoked in the analysis of standing before the $1970 \mathrm{~s}^{41}$

\section{B. The Burger Court: Constitutionalization of Standing}

Under Chief Justice Burger, ${ }^{42}$ the Supreine Court cut back on the liberal standing doctrine developed under Chief Justice Warren. ${ }^{43}$ The Court began to redraw the rules of standing and, more significantly, to locate the source of standing doctrine squarely in the Constitution. ${ }^{44}$ While scholars have long debated the true motivation behind the Burger Court's constitutionalization of standing, ${ }^{45}$ the effect of the Court's jurisprudence in

37. Gene R. Nichol, Is There a Law of Federal Courts?, 96 W. VA. L. Rev. 147, 148-49 (1993) (internal citations omitted).

38. Id. at 149.

39. See id. at 149-51. Professor Nichol notes that other procedural mechanisms were also introduced during the Warren Court era, including criminal procedural safeguards and the provision of a federal forum for First Amendment actions against state actors. Id.

40. See generally CHEMERINSKY, supra note 9, at 57-58.

41. This is not to say that the Warren Court did not recognize a relationship between the standing inquiry and Article III's case or controversy requirement. Rather, standing during this period was viewed as a prudential tool that served the purpose of ensuring that matters were presented to courts in the form of focused, narrowly drawn "cases and controversies." Flast, 392 U.S. at 94-95.

42. Chief Justice Burger was confirmed by the Senate on June 9,1969 and served as Chief Justice until he resigned at the end of the 1985 Term.

43. See Albert W. Alschuler, Failed Pragmatism: Reflections on the Burger Court, 100 HaRV. L. REv. 1436, 1442 (concluding that "the Burger Court waged a prolonged and rather bloody campaign of gnerrilla warfare" whicb "typically left the facade of Warren Court decisions standing while it attacked these decisions from the sides and underncath"); see also Gene R. Nichol, Jr., Injury and the Disintegration of Article III, 74 CoLUM. L. REv. 1915, 1923 (1986).

44. Nichol, supra note 43 , at 1915 (noting that in reaction to both "a burgeoning federal docket and to perceived dangers from the aggrandizement of judicial power, the Supreme Court has attempted to pour content into Article IIl by constitutionalizing a variety of jurisdictional inquiries, including standing doctrine").

45. For example, Professor Richard Pierce argues that politics were at the root of the Burger Court's restrictive standing jurisprudence:

At the time, the federal judiciary again included a large number of activist judges-albeit

liberal activists rather than the conservative activists who concemed Brandeis and Frankfurter. Given the opportunity to do so, many of the federal judges who sat during the 1970's and 1980's would devise creative interpretations of the Constitution. They would then rely on these interpretations as the basis to wrest control of foreign policy from the politically accountable branches, to exereise plenary power over many important govermmental institutions such as schools and prisons, and to force executive branch agencies to reallocate 
this area was to limit both the access of litigants seeking to adjudicate matters of broad social concern, and the authority of Congress to vest such power in the citizenry. ${ }^{46}$

As the Burger Court moved away from the flexible, case-by-case approach of prudential standing limitations, and towards a constitutionalized view of standing, it developed a new test for determining whether Article III standing had been satisfied. First, in Warth v. Seldin, ${ }^{47}$ the Court cautioned that, as a matter of constitutional interpretation, courts may not recognize "generalized grievances"48 as a basis for standing, but

\footnotetext{
their scarce resources in ways the judges preferred. The circumstances in which the Burger Court applied its expanded version of standing strongly suggest that the Burger Court was trying once more to insulate the politically accountable branches of government from the constant assaults of activist judges. An expanded version of standing law was only one of many tools the Burger Court used in an effort to accomplish this policy goal during the $1970^{\circ}$ 's and 1980's.
}

Richard J. Pierce, Jr., Is Standing Law or Politics?, 77 N.C. L. Rev. 1721, 1768-69 (1999). Other scholars have been even more cynical about the Burger Court's standing jurisprudence. See, e.g., Stearns, supra note 23, at 385 ("h1 the Burger and Rehnquist Courts, standing became a necessary vehicle to prevent the irrationality of the Court's own creation. Even an institution that could not agree either on how to define or resolve divisive issues could agree on one principle: Better not to decide, or to let lower federal courts decide, the most difficult issues presented than to condone outcoines no more predictable than a roll of the dice.").

46. Interestingly, Warren Burger's tenure as Chief Justice began with a few very liberal standing opinions. For example, in Association of Data Processing Service Organizations v. Camp, 397 U.S. 150 (1970), an association of data processors brought suit to challenge a rule permitting national banks to provide data processing services to bank customers and other banks. The association claimed that its members had suffered an Article III injury as a result of the mcreased competition. Id. at 151-52. The issue before the Court was whether the association was "aggrieved by agency action within the meaning of a relevant statute" pursuant to the Adininistrative Procedure Act. Id. at 153 . In an opinion written by Justice William O. Douglas, the Court replaced the previous test for standing, which called for determining whether the plaintiff had a legally protected interest in the matter, with a factual inquiry into the existence of harm. The Court held that the question of standing required inquiry into whether the interest sought to be protected by the complainant is "arguably within the zone of interests" to be "protected or regulated by the statute or constitutional guarantee in question. ... That interest, at times, may refiect 'aesthetic, conservational, and recreational' as well as econoinic values." Id. at 153-54. Data Processing therefore represented the Court's first extended discussion of "injury-in-fact" as an element of standing, as well as the force of legislative authority on the question of standing. See also United States v. Students Challenging Regulatory Agency Procedures, 412 U.S. 669, 675-76, 690 (1973) (recognizing that law students had standing when they alleged that a railroad freight rate increase would encourage the use of nonrecyclable products, thereby creating nore waste and fewer natural resources and causing the students to suffer economic, recreational, and aesthetic injuries). These decisions have been recognized as perhaps the "all-time high in judicial hberality on a question of standing." 4 KeNNETH C. DAVIS, AdMInISTRATIVE LAw Treatise $§ 24: 18$, at 283 (2d ed. 1983); see also Gene R. Nichol, Jr., Abusing Standing: A Comment on Allen v. Wright, 133 U. PA. L. REV. 635, 635 (1985) ("The Burger Court's treatment of standing requirement has been, at best, erratic. Access has, on oceasion, been liberally granted. More often, the doctrine has been employed without consistent rationale to fence out disfavored federal claims. This vacillation has created a body of Article III decisions that ranks among the inost uniformly criticized of the entire Burger Court legacy.").

47. 422 U.S. 490 (1975).

48. Compare Flast v. Cohen, 392 U.S. 83, 93-97 (1968), where the Court stated that the prudential ban on "generalized grievances" was compelled by "policy considerations" such as preserving judicial resources, rather than the mandates of the Constitution. See also CHEMERINSKY, supra note 9 , at 89-90. 
must require a showing of "distinct and palpable injury." ${ }^{\text {"49 }}$ Essentially abandoning Flast's "adverseness" standard for a "concrete imjury" requirement, the Warth Court held that "concrete injury, whether actual or threatened, is that indispensable element of a dispute which serves in part to cast it in a form traditionally capable of judicial resolution .... Only concrete injury presents the factual context within which a court... is capable of making decisions." ${ }^{50}$ Then, in Simon v. Eastern Kentucky Welfare Rights Organization, ${ }^{51}$ the Court adopted two additional elements to the standing inquiry: a plaintiff must show that his injury was caused or would likely be caused by the conduct of the defendant, and that the injury would be redressed by the relief sought. ${ }^{52}$ Finally, in Valley Forge Christian College v. Americans United for Separation of Church and State, Inc. ${ }^{53}$ the Court summarized its standing jurisprudence as a three-pronged test of injury-m-fact, causation, and redressability. ${ }^{54}$ By the late 1970 s, the Court had applied all three of these newly constitutionalized requirements, injury-in-fact, causation, and redressability, to deny plaintiffs standing in a number of contexts. ${ }^{55}$

In addition to constructing the three-pronged test for constitutional standing, the Burger Court also began to stress the constitutional nature of standing doctrine and its roots in separation of powers principles. ${ }^{56}$ In Schlesinger v. Reservists Committee to Stop the $\mathrm{War}^{57}$ and United States $v$. Richardson ${ }^{58}$ decided the same day, the Court connected the injury-in-fact

49. Warth, 422 U.S. at 499-501, 507 (denying standing to litigants challenging local zoning ordinances as having the purpose and effect of excluding low and moderate income individuals; finding that petitioners had failed to allege injury as a consequence of the defendant's actions because none of the petitioners had "a present interest" in any property in the area, and that petitioners had failed to demonstrate redressability because they "rely on little more than the remote possibility, unsubstantiated by allegations of fact, that their situation might have been better had respondents acted othervise, and might improve were the court to afford relief'); see also Gladstone Rcaltors v. Village of Bellwood, 441 U.S. 91, 99-100 (1979) (finding that questions of "broad social import where no individual rights would be vindicated" do not satisfy standing requirement).

50. Warth, 422 U.S. at 501.

51. 426 U.S. 26 (1976).

52. Id. at 38 (denying standing to indigents challenging IRS regulations allowing hospitals which refuse to treat indigents to maintain tax-exempt status; finding that petitioners had failed to demonstrate that the IRS's actions caused the hospitals to deny treatment).

53. 454 U.S. 404 (1982).

54. Id. at 472 .

55. See Stearns, supra note 23, at 387 (noting that the Burger Court "effectively metamorphosed three common law tort analogies-injury-in-fact, causation, and redressability-to the level of quasi-constitutional doctrine").

56. TRIBE, supra note 34, at 108 (observing that the Burger Court changed standing inquiry to incorporate separation of powers concerns).

57. 418 U.S. 208, 220 (1974) (denying standing, where group claimed standing based on its 1nembers' status as taxpayers and citizens, on grounds that "standing to sue may not be predicated upon an interest of the kind ... which is held in common by all members of the public").

58. 418 U.S. 166, 175 (1974) (denying taxpayer standing on grounds that respondent lacked a personal stake in the outcome of the litigation and that the alleged injury was one held in common by the citizenry). 
test to the separation of powers doctrine for the first time. In Schlesinger, Chief Justice Burger noted that concrete injury was essential for standing because only Congress is competent to deal with abstract, political questions which affect the citizenry at large. ${ }^{59}$ In Richardson, the Chief Justice stated that if no individual suffers concrete, particularized harm, the dispute is properly "committed to the surveillance of Congress, and ultimately to the political process," not to the judiciary. ${ }^{60}$ Taken together, Schlesinger and Richardson reveal the Burger Court's insistence on adjudicating only those cases in which the injuries alleged are personal to the litigants, and on leaving matters of broader social concern to "the political process." As such, the emerging constitutionalized standing doctrine left little room for public law litigation.

The Burger Court also described the newly constitutionalized "concrete injury" requirement as independent of any statutory standing rights created by Congress. ${ }^{61}$ In Warth, for example, the Court stated that "Congress may grant an express right of action to persons who otherwise would be barred by prudential standing rules. Of course, Article III's requirement remains: the plaintiff still must allege a distinct and palpable injury to himself." ${ }^{\prime 62}$ Under the Burger Court's view of separation of powers, "Art. III judicial power exists only to redress or otherwise to protect against injnry to the complaining party."63

Even this brief overview of the Burger Court's standing jurisprudence reveals that the flexible standards used by the Warren Court to provide litigants greater access to federal courts "were used by the Court's successors to constitutionalize new barriers to the developing public litigation model." 64 By requiring that federal court plaintiffs satisfy the constitutionalized three-prong standing test, regardless of whether those plaintiffs relied on "the Constitution itself, or a direct congressional grant of standing," $" \% 5$ the Burger Court's decisions in this area liad the

59. Schlesinger, 418 U.S. at $221 \mathrm{n} .10$ ("The legislative function is inherently general rather than particular and is not intended to be responsive to adversaries asserting specific claims or interests peculiar to themselves.").

60. Richardson, 418 U.S. at 179.

61. See Gene R. Nichol, Standing on the Constitution: The Supreme Court and Valley Forge, 61 N.C. L. REV. 798, 809 (noting that Schlesinger and Richardson "teach quite clearly that standing cannot be predicated merely upon the 'harm' a citizen sustains as the result of the government's failure to comply with the Constitution").

62. Warth v. Seldin, 422 U.S.490, 501 (1975); see also Allen v. Wright, 468 U.S. 737, 754 (1984) (stating that "an asserted right to have the Government act in accordance with law" is by itself insufficient to confer jurisdiction in federal court).

63. Warth, 422 U.S. at 499.

64. Nichol, supra note 37 , at 153.

65. Stearns, supra note 23 , at $389-90$. 
unmistakable effect of proscribing Congress from vesting private actors with the authority to redress injuries suffered by the citizenry at large. ${ }^{66}$

\section{The Rehnquist/Scalia Court: Lyons, Lujan, and Limits on Statutory Standing}

In the early 1980s, the Supreme Court handed down a number of major standing limitation decisions, ${ }^{67}$ indicating that the pendular swing towards restricting citizen access to federal adjudication was far from over. ${ }^{68}$ This increasingly restrictive regime was eventually enforced even against the apparent will of Congress: in its 1984 decision in City of Los Angeles $v$. Lyons, ${ }^{69}$ the Court for the first time denied standing to a plaintiff bringing suit pursuant to a specific grant of statutory authority and explicitly questioned the congressional power to vest such power in private litigants. ${ }^{70}$

66. See Craig R. Gottlieb, Comment, How Standing Has Fallen: The Need To Separate Constitutional And Prudential Concerns, 142 U. PA. L. REv. 1063, 1082 (1994); Stearns, supra note 23, at 392 (noting that "by superimposing standing's injury-in-fact requirement onto cases in which plaintiffs rely upon federal statutes, the Court has signaled a serious intrusion into Congress's power to define new judicially cognizable injuries").

67. See, e.g., Allen, 468 U.S. at 737; City of Los Angeles v. Lyons, 461 U.S. 95 (1983) (denying constitutional standing to seek injunctive relief to victim of police chokehold on ground that likelthood of repetition as to him posed insufficient threat to establish required injury); Valley Forge Christian Coll. v. Americans United for Separation of Church \& State, Inc., 454 U.S. 464 (1982).

68. But see Abram Chayes, The Supreme Court, 1981 Term-Foreword: Public Law Litigation and the Burger Court, 96 HARV. L. REv. 4 (1982) ("[T]he great standing expansion of the 1960's remains relatively untouched; in the vast majority of public law cases, it has been possible to turn up a plaintiff who has suffered the requisite injury in fact."). Professor Chayes wrote these words, however, prior to the Court's decisions in Allen and Lyons.

69. 461 U.S. 95 (1983).

70. The Court first began to articulate a nascent equitable standing requirement in the mid-1970s. See O'Shea v. Littleton, 414 U.S. 488 (1974); Rizzo v. Goode, 423 U.S. 362 (1976). O'Shea was a class action alleging that a county magistrate and associate judge had deprived minorities of constitutional rights through a continuing pattem of illegal bond sctting, discriminatory sentencing and jury fee praetices. 414 U.S. at $490-91$. The $O$ 'Shea plaintiffs sought no damages, but requested the unconstitutional practices be enjoined. $I d$. at 492 . The Court, in a six to three decision, found that plaintiffs lacked standing to seek federal equitable relief because they had failed to allege injury, either past or threatened, sufficient to warrant judicial intrusion into the state criminal justice system. Id. at 493-94. The Court further noted that even if plaintiffs had suffered past injury due to these alleged practices, "past exposure to illegal conduct does not in itself show a present case or controversy regarding injunctive relief . . . if unaccompanied by any continuing, present adverse effects." Id. at 49596.

Similarly, the plaintiffs in Rizzo, who had at trial proven systemic, widespread constitutional violations by the Philadelphia Police Department, 423 U.S. at 366-69, obtained a district court injunctive order requiring the department to create "a comprehensive program for improving the handling of citizen complaints alleging police misconduct." Id. at 365. Relying on its decision in $O$ 'Shea, the Court found that plaintiffs had not proven that the injuries they suffered in the past were likely to recur because their claim to "real and immediate" injury did not lie "upon what the named petitioners might do to them in the future." Id. at 372. The Court therefore reversed the grant of injunctive relief for lack of standing to seek such relief. Id. at 381. 
In Lyons, Los Angeles police officers applied a cliokeliold to a black motorist during a routine traffic stop, a department-authorized practice that had resulted in numerous fatalities to minority detamees. ${ }^{71}$ Sumg under 42 U.S.C. Section 1983, which expressly authorizes persons deprived of civil rights to seek injunctive rehef against future violations, ${ }^{72}$ plaimtiff Lyons sought to enjom the Los Angeles Police Department ("LAPD") from employing chokeholds where there was no threat of deadly force. ${ }^{73}$ The district court found for the plaintiff and enjomed the use of chokeliolds by the LAPD "under circumstances which do not threaten death or serious bodily injury. ${ }^{374}$ The Ninth Circuit affirmed. ${ }^{75}$

The Supreme Court reversed, holding that the express availability of injunctive relief under Section 1983 was not dispositive. Drawing on the redressability element of Article III standing analysis and the constitutionalized prohibition against generalized grievances, the Court instead held that Lyons lacked "equitable standing" to seek injunctive relief in the absence of a showing that he himself was "substantially certain" to suffer the same mjury agam at the hands of the LAPD. ${ }^{76}$

The Court's decision in Lyons illustrates graphically the impact of the constitutionalization of standing doctrine upon Congress's ability to vest broad enforcement rights in private citizens. In the wake of Lyons, Congress simply lacks the constitutional authority to vest in private citizens the power to seek injunctive relief against unconstitutional or unlawful practices where these citizens cannot independently meet the Court's stringent, constitutional standing requirements. ${ }^{77}$ Indeed, a 1991

71. Lyons, 461 U.S. at 115-16 (Marshall, J., dissenting). When the plaintiff, Adolph Lyons, exited his car after being pulled over for a burned-out taillight, he encountered two LAPD officers with drawn revolvers who directed him to face the vehicle, place his hands behind his head and spread his legs. Their pat-down search revealed no weapons, but when Lyons began to lower his arms, one of the officers apphed a chokehold which rendered him unconscious and permanently damaged his larynx. When Lyons regaimed conscionsness, he was on the ground spitting up blood and had urinated and defecated. He could not speak due to the damage to his larynx. The officers then gave him a ticket for the bumed-out taillight, and let him go. Id. at 114-15 (Marshall, J., dissenting).

72. 42 U.S.C. $\$ 1983$ (1994).

73. Lyons, 461 U.S. at 98.

74. Id. at 99-100. The district court also required an improved police training program on the proper use of the chokehold, as well as regular reporting and record keeping of incidents involving the application of chokeholds by the police. Id. at 100 .

75. Lyons v. City of Los Angeles, 615 F.2d 1243, 1246-47 (9th Cir. 1980), rev'd, 461 U.S. 95 (1983). The per curiam opinion found that there was a sufficient likelihood that Lyons would again be stopped and subjected to the unlawful use of force to confer standing and to warrant the issuance of an injunction. Id.

76. Lyons, 461 U.S. at 111. The Lyons Court relied, in part, on its earlier decisions in $O$ 'Shea v. Littleton, 414 U.S. 488 (1974), and Rizzo v. Goode, 423 U.S. 362 (1976). See Lyons, 461 U.S. at 10310; see also supra note 70 .

77. See Richard H. Fallon, Of Justiciability, Remedies and Public Law Litigation: Notes on the Jurisprudence of Lyons, 59 N.Y.U. L. REV. 1, 23 (1984) (noting that the "constitutionalization of remedial standing" defies "implicit policies of energing public law," and also "diminishes the power of 
congressional attempt to circumvent the equitable standing doctrine by authorizing victims of police misconduct to enjoin unconstitutional patterns or practices died in committee. ${ }^{78}$

The implications of the equitable standing doctrine are immense: many of the landinark constitutional cases and great social reforms of the last half-century were driven by private plaintiffs, such as Brown, ${ }^{79}$ Roe, ${ }^{80}$ and Bakke, ${ }^{81}$ who brought suit under federal civil rights statutes which authorized them to seek injunctive or declaratory relief. In bringing these cases, plaintiffs sought not only redress for themselves for the harms that they had personally suffered, but also protection for society at large against those harms. The plaintiffs in these cases and in many others would have lacked standing under the doctrine of Lyons. ${ }^{82}$

Eight years after Lyons, in Lujan v. Defenders of Wildlife, ${ }^{83}$ the Court denied standing to private litigants asserting claims under citizen suit provisions of a federal environmental statute for injunctive and declaratory relief $^{84}$ Seeking to establish the requisite injury-in-fact required by the Court's constitutionalized standing jurisprudence, two environmental

the courts, and potentially the capacity of Congress to protect federal rights and to provide remedies for their violation").

78. In 1991, House Democrats introduced the Police Accountability Act, H.R. 2972, 102d Cong. (1991), which prohibited police officers from engaging in a "pattern or practice" of conduct violative of civil rights and authorized the Attomey General and victims of such conduct to "obtain appropriate equitable and declaratory relief to eliminate the pattern or practice." Constitutional and political pressures threatened the viability of the provision and the Conference Committee eventually compromised by eliminating the citizen suit provision. See Terence Moran \& Daniel Klaidman, Police Brutality Poses Quandary for Justice Department, Legal TIMEs, May 4, 1992, at 1 (discussing political opposition from the Bush Justice Department and police advocacy groups that led to the demise of the Act). Three years later, Congress enacted a statute, the Violent Crime Control and Law Enforcement Act, 42 U.S.C. $\S 14141$ (1994 \& Supp. 1998), which specifically empowers the Attomey General to uncover and sue to enjoin unconstitutional police practices, but which grants victims of such practices no enforcement role. See Gilles, supra note 2, at 1404-08 (discussing the efficacy of $§ 14141$ ); see also infra text accompanying notes 255-265 (considering the implications of the representational standing doctrine in police misconduct litigation).

79. Brown v. Bd. of Educ., 349 U.S. 294 (1955).

80. Roe v. Wade, 410 U.S. 113 (1973).

81. Regents of the Univ. of Cal. v. Bakke, 438 U.S. 265 (1978).

82. For example, Professor Tribe argues that, under a literal interpretation of Lyons, the Bakke case would not have been justiciable because the plaintiff, a white male who had been denied admission to medical school because of a policy requiring that a set number of minority applicants be admitted, would not have been able to demonstrate with certainty that he would be admitted to a future class but for the admission policy. TriBE, supra note 34, at 117 . Silmilarly, the plaintiff in Roe $v$. Wade could not have demonstrated that she would again be pregnant and seek an abortion. Id. at 118; see also Gilles, supra note 2, at 1386 ("We have lost, in the post-Lyons world, the powerful force of the citizenry as a direct agent in effecting meaningful social change through America's courts.").

83. 504 U.S. 555 (1992).

84. Lujan involved a challenge by an environmental group to a 1986 Department of Interior revision of regulations in the Endangered Species Act conceming consultation processes where federally funded projects threaten endangered species. Specifically, the group claimed that the lack of consultation concerning federally funded activities "increases the rate of extinction of endangered species," causing injury to its members. Id. at 562. 
group members claimed that certain federally-funded projects abroad were a threat to endangered species of particular interest and alleged that the government's actions were a direct cause of their potential injury in being unable to observe or enjoy these species. ${ }^{85}$

The Supreme Court, in an opinion authored by Justice Scalia, began by explicitly recognizing its gradual constitutionalization of standing doctrine. ${ }^{86}$ The Court acknowledged that while "some of [the] elements" of standing doctrine "express merely prudential considerations that are part of judicial self-government, the core component of standing is an essential and unchanging part of the case-or-controversy requirement of Article III."87 Having thus established the constitutional rather than prudential concerns at issue in Lujan, the Court then turned to the now substantive question of citizen suit standing.

In reversing the lower court, ${ }^{88}$ the Lujan Court applied its constitutionalized standing requirements and held that the plaintiffs' allegations fell short of establishing the requisite mjury-in-fact and redressability. First, applying the equitable standing bar of Lyons, the Lujan Court found that "past exposure to illegal conduct does not in itself show a present case or controversy regarding injunctive relief ... if unaccompanied by any continuing, present adverse effects." 989 Thus, the Lujan plaintiffs' assertions of injury based on past experiences with endangered species failed to meet the "imminent injury" standard of Article III standing. ${ }^{90}$ Second, Justice

85. Amy Skilbred, a member of the Defenders of Wildlife, alleged that federal funding of the Mahaweli project in Sri Lanka "will seriously reduce endangered, threatened, and endemic species habitat including areas that I visited ..., [which] may severely shorten the future of these species." Id. at 563. That threat, she averred, caused her direct liarm because she "intend[s] to return to Sri Lanka in the future and hope[s] to be more fortunate in spotting at least the endangered elephant and leopard." Id. In a subsequent deposition, she reiterated ber intention to return to Sri Lanka, but confessed she had no current plans. Id. at 563-64. Joyce Kelly, another Defenders member, alleged that she had "observed the traditional habitat" of the Nile crocodile and "intend[s] to do so again"; she further alleged that she would "suffer harm in fact as the result of [the] American role in overseeing the rehabilitation of the Aswan High Dam on the Nile and in developing Egypt's Master Water Plan," as these projects would result in further endangering the traditional habitat of the Nile crocodile. $I d$. at 563 (internal quotations omitted).

86. "Over the years, our eases have established that the irreducible constitutional minimum of standing contains three elements ...," mjury-in-fact, causation, and redressability. Id. at 560-61.

87. Id. at 560 (citing Allen v. Wright, 468 U.S. 737, 751 (1984)).

88. The Eighth Circuit had granted plaintiffs standing based on the citizen suit provisions of the Endangered Species Act, which made clear that "any person may commence" a civil suit on his own behalf "to enjoin [the] violation of any ... provision of the [Act]." Defenders of Wildlife v. Lujan, 911 F.2d 117, 121 (8th Cir. 1990), rev'd, 504 U.S. 555 (1992).

89. Lujan, 504 U.S. at 564 (quoting City of Los Angeles v. Lyons, 461 U.S. 95, 102 (1983)) (internal quotations omitted).

90. Justice Scalia found that the fact that the affiants "had visited" the areas allegedly threatened by federally funded projects "proves nothing." "The ... profession of an 'intent' to return to the places they had visited before ... without any description of concrete plans, or indeed even any specification of when the soine day will be-do[es] not support a finding of the "actual or immiment' injury that our cases require." Id. 
Scalia rejected the environmental group's various theories of standing based either on injury to the environment or on the members' interest in observing or working with endangered species. ${ }^{91}$ Characterizing these alleged injuries as "abstract," generalized grievances, the Lujan Court found the litigants had failed the injury-in-fact prong of the Article III standing test. ${ }^{92}$

Third, in denying standing to citizen suit plamtiffs, Lujan raised separation of powers concerns regarding legislation authorizing private individuals to vindicate public interests. As the Court explained, "[t]o permit Congress to convert the undifferentiated public interest ... into an 'individual right' vindicable in the courts is to permit Congress to transfer from the President to the courts the Chief Executive's most important constitutional duty, to "take Care that the Laws be faithfully executed."

In these three deft movements, the Lujan Court solidified the legitimacy of the constitutionalized standing inquiry, revealed the subjectiveness and malleability of the injury-in-fact analysis and, finally, forged a direct and seemingly immutable link between Article III standing and separation of powers concerns. This latter point is perhaps the most significant aspect of the Lujan decision, as it casts substantial doubt upon the authority of Congress to vest standing in private litigants seeking to vindicate broad public interests. While acknowledging that the citizen suit provision was intended to supplement federal oversight and enforcement of these statutorily created interests, the Court refused to allow private citizen standing based solely on this Congressional mandate. Rejecting the argument that injury-in-fact is satisfied "by congressional conferral upon

91. Id. at 565. The group argued, for example, that it suffered injury as "part of a contiguous ecosystem adversely affected by a funded activity." Id. The Lujan Court rejected this "ecosystem nexus" theory, finding that a plaintiff claiming injury from environmental damage "must use the area affected by the challenged activity and not an area roughly 'in the vicinity' of it." Id. at 566 . Respondents also alleged injury based on their interest in studying or seeing the endangered animals threatened by funded activity. Id. Again, the Court rejected the "animal nexus" and "vocational nexus" theories of standing, finding that under these theories, "anyone who goes to see Asian elephants in the Bronx Zoo, and anyone who is a keeper of Asian elephants in the Bronx Zoo, has standing." Id. According to the Court, "it goes heyond the limit ... and into pure speculation and fantasy to say that anyone who observes or works with an endangered species, anywhere in the world, is appreciably harmed by a single project affecting some portion of that species with which he has no more specific connection." Id. at 567.

92. Id. at 570-72.

93. Id. at 577 (citing U.S. CoNST. art. II, § 3). Numerous scholars have been critical of the Lujan decision. See, e.g., Keith Werhan, Delegalizing Administrative Law, 1996 U. ILL. L. REv, 423, 455 (1996) (noting that the Lujan Court constitutionalized the generalized grievance principle and subjected statutory standing provisions to judicial review); Patti A. Meeks, Justice Scalia and the Demise of Environmental Law Standing, 8 J. LAND UsE \& ENVTL. L. 343, 364 (1993) ("Scalia has apparently used Lujan as a stepping stone towards constitutionalizing the generalized grievance standing limitation."); Gene R. Nichol, Jr., Justice Scalia, Standing and Public Law Litigation, 42 Duke L.J. $1141,1167-68$ (1993) (reasoning that Justice Scalia's approach to standing threatens plaintiffs' ability to bring "public law litigation" generally and "threatens to constitutionalize an nnbalanced scheme of regulatory review"). 
all persons of an abstract, self-contained ... 'right," the Lujan Court held that constitutional standing is not satisfied where a citizen claims "only harm to his and every citizen's interest in proper application of the Constitution and laws, and seeking relief that no more directly and tangibly benefits him than it does the public at large. ${ }^{994}$

In the wake of Lyons and Lujan, Congressional authority to vest private individuals with standing to bring suit to vindicate broad public interests was questionable. ${ }^{95}$ Perhaps more importantly, these denials of standing based on constitutional rather than prudential grounds made it impossible for Congress to "legislate around" the Court's decisions in order to increase or improve the private role in police brutality and environmental litigation, as well as in other areas of public law litigation. Although the Court's standing jurisprudence at the end of the twentieth century was inconsistent in denying standing to "private attorneys general" in some cases ${ }^{96}$ while granting standing in others, ${ }^{97}$ the general tenor of its decisions revealed a limiting principle at work. ${ }^{98}$

94. 504 U.S. at 573-74.

95. Patricia M. Wald, The Cinematic Supreme Court: $1991-92$ Term, 7 ADMin. L. J. AM. U. 238, 239-40 (1993) (noting that "by constitutionalizing standing to the degree that it does-some might even say 'trivializing' it to the minutiae of asking if you have your return ticket to Sri Lanka-the Court [in Lujan] prevents Congress from broadening the standard").

96. For example, in Steel Co. v. Citizens for a Better Environment, 523 U.S. 83 (1998), the Court held that an environmental group lacked standing to bring a citizen suit based on past violations of an environmental statute. Focusing on the redressability prong of standing analysis, the Court held that in the absence of ongoing violations, "[n]oue of the specific items of relief sought, and none that we can envision as 'appropriate' under the general request, would serve to reimburse respondent for losses caused by the late reporting, or to eliminate any effects of that late reporting upon respondent." $I d$. at 1018. Again, the decision in Steel Co. represents the constitutionalization of a traditionally prudential doctrine, making it impossible for Congress to "fix" the result by making clear its intent that citizens be able to bring suit for even wholly past violations. See Craig N. Johnston, 1998-The Year In Review, 29 ENVTL. L. 69, 76 (1999).

97. The same term that Steel Co. was decided, the Court also ruled in Federal Election Commission v. Akins, 524 U.S. 11 (1998), that a group of voters had standing to bring suit under the Federal Election Campaign Act of 1971 to challenge the Federal Election Commission's refusal to compel a lobbying organization to disclose imfornation. And two terns later in Friends of the Earth, Inc. v. Laidlaw Environmental Services, 528 U.S. 167 (2000), the Court held that an environmental group had standing to bring a citizen suit seeking both civil penalties and injunctive relief agaiust a violator of the Clean Water Act. These two decisions, standing in stark contradiction to recent precedent, have led commentators to wonder whether the Court is returning to a nore liberalized view of standing doctrine. See, e.g., Cass R. Sunstein, Informational Regulation and Informational Standing: Akins and Beyond, 147 U. PA. L. REv. 613 (1999) (arguing that $A$ Alins Court appears to have held, in contradiction to recent precedent, that any citizen has standing to sue under FECA; that Congress is permitted to grant standing to all or many citizens, even if they are seeking to redress a "generahzed grievance"; that the key question, im cases involving information or anything else, is what the relevant source of law actually says; and that Article III is no barrier to suits brought by citizens whose interests are not substantially different from those of the citizenry as a whole). A close reading of Akins and Laidlaw reveals, however, that these grants of standing were based on factual distinctions rather than true constitutional imterpretation.

98. Of course, focusing solely on the Court's standing jurisprudence tends to distort the full panoply of its decisions over the last thirty years. So, for example, the Burger Court did not engage in 
Then, in 1999, the Court granted certiorari in Vermont Agency of Natural Resources $v$. United States ex rel. Stevens, ${ }^{99}$ a case brought by a private citizen under the qui tam provisions of the False Claims Act, ${ }^{100}$ which provides for liability against "any person" who presents a false money claim to the federal government. ${ }^{101}$ Qui tam actions had long been criticized as unconstitutional ${ }^{102}$ because they authorize a private litigant to bring suit on behalf of the government where they themselves suffer no cognizable injury-in-fact. ${ }^{103}$ Although the parties and the lower courts had not addressed the standing issue, the Court determined that a threshold question presented by Stevens was whether the private citizen-plaintiff, termed a "relator" under the qui tam statute, had Article III standing to bring suit on behalf of the government. The Court's decision on the standing issue is the focus of the next Part.

II

VERMONT AGENCY OF NATURAL RESOURCES V. U.S. EX REL. STEVENS: The Question of Relator Standing IN Qui TaM Litigation

\section{A. Facts and Procedural History of Stevens}

Jonathan Stevens was employed by the Vermont Agency of Natural Resources ("VANR") from 1993 to $1994 .{ }^{104}$ During the course of his

the major, anticipated "counter-revolution" against Warren Court decisions in areas such as desegregation or school prayer; indeed, the Burger Court even found new arenas for judicial activism. The Burger Court embraced equal protection as grounds for the discrimination claims of women, and unceremoniously scrapped the nation's anti-abortion laws in Roe v. Wade. See generally VINCE BLASI, The Burger Court: The Counter-Revolution That Wasn't (1983).

99. I20 S. Ct. 1858, 1861 (2000). For the grant of certiorari, see 527 U.S. 1034 (1999).

100. 31 U.S.C. $\$ \$ 3729-3733$ (1994).

101. Stevens, 120 S. Ct. at 1858,1860 (citing 31 U.S.C. $\$ 3729$ ).

102. See, e.g., Sean Hamer, Lincoln's Law: Constitutional and Policy Issues Posed by the Qui Tam Provisions of the False Claims Act, 6 KAN. J.L. \& PUB. PoL'y 89 (1997); James T. Blanch, Note, The Constitutionality of the False Claims Act's Qui Tam Provision, 16 HaRv. J.L. \& PuB. PoL'y 701 (1993); Frank A. Edgar, Jr., Comment, "Missing the Analytical Boat": The Unconstitutionality of the Qui Tam Provisions of the False Claims Act, 27 IDAHO L. REv. 319 (1990); Robert E. Johnston, Note, 1001 Attorneys General: Executive-Employee Qui Tam Suits and the Constitution, 62 GEO. WASH. L. REv. 609 (1994); Ara Lovitt, Note, Fight for Your Right to Litigate: Qui Tam, Article II, and the President, 49 Stan. L. Rev. 853 (1997); John P. Robertson, Comment, The False Claims Act, 26 ARIz. ST. L.J. 899 (1994).

103. See, e.g., James T. Blanch et al., Citizen Suits and Qui Tam Actions: Private ENForcement of Public Policy (1996); Gretchen L. Forney, Qui Tam Suits: Defining the Rights and Roles of the Government and the Relator Under the False Claims Act, 82 MinN. L. REv. 1357 (1998); Thoinas R. Lee, Comment, The Standing of Qui Tam Relators Under the False Claims Act, 57 U. CHI. L. REv. 543 (1990).

104. Stevens, $120 \mathrm{~S}$. Ct. at 1863 . VANR is the state agency responsible for the implenentation, administration and enforceinent of various federal and state environmental laws, including the Clean Water Act, 33 U.S.C. $\S 1251$ (1994), and Safe Drinking Water Act, 42 U.S.C. $\S 300 f$ (1994), in addition to various state laws that implement these federal statutes. See, e.g., VT. STAT. ANN. tit. 10. VANR works in partnership with the Environmental Protection Agency ("EPA") through a system of grants and reporting. See, e.g., 33 U.S.C. $\S 1329$ (a), (b). 
employment, Stevens allegedly discovered that VANR had systematically defrauded the United States government by nistructing its employees to prepare documents that falsely certified that those employees had worked on matters funded by certain federal grants administered by the EPA. ${ }^{105}$ In essence, Stevens, in classic whistleblower fashion, believed that VANR's employee time records constituted false claims to the federal government in violation of the False Claims Act ("FCA") $)^{106}$ and set out to prove as nuch.

105. Stevens, 120 S. Ct. 1861.

106. Id. at 1861; see also False Claims Act, 31 U.S.C. \$ 3729-3733. The Act provides that anyone who presents a false money claim to the federal government shall be liable for double or treble damages and civil penalties of up to $\$ 10,000$ per false claim. $\$ 3729$. The FCA, which authorizes the government to bring civil actions against those who defraud it, contains a qui tam enforcement provision, whereby private citizens with independent knowledge of fraud perpetrated agamst the government may sue to recover the fruits of the fraud. $\$ 3730(b)(1)$. Under the qui tam provisions of the FCA, any person may bring a civil action "for the person and for the United States Government" to recover damages and penalties. $\$ 3730(b)(1)$. Qui tam is short for the Latin phrase, "qui tam pro domino rege, quam pro se ipso in hac parte sequitur," which literally means "who prosecutes this suit as well for the king as for himself." WhLlam BLackstone, CoMmentaries on the Law of ENGLAND 161 (1768).

Congress enacted the original FCA in 1863 "to assist in ferreting out unscrupulous defense contractors who committed fraud against the Union army by delivering bullets loaded with sawdust." Joan R. Bullock, The Pebble In the Shoe: Making the Case For the Government Employee, 60 TENN. L. REV. 365, 368-69 (1993); see also S. REP. No. 99-345, at 8, reprinted in 1986 U.S.C.C.A.N. 5266, 5269; Lovitt, supra note 102, at 856 . The provision was intended to "supplement the nascent prosecutorial capabiities of the Attorney General." Id. (noting that when Congress enacted the FCA in 1863, the Attorney General's office was still in its infancy and the Department of Justice did not yet exist); see also John T. Boese, When Angry Patients Become Angry Prosecutors: Medical Necessity Determinations, Quality of Care and the Qui Tam Law, 43 ST. Lous U. L.J. 53, 60 (1999) (noting that the qui tam provision of the original FCA was a response to "the absence of effective government resources to investigate and prosecute fraud against the government").

Congress amended the statute in 1943 to limit the circumstances under which a private individual could bring suit. See 89 Conc. REc. 7606 (Sept. 17, 1943). Underlying the 1943 amendment was the government's belief that it could discover and prosecute fraud on its own, without the aid of private individuals. Gilles, supra note 2, at 1422. From 1943 to 1986, actions under the FCA became increasingly rare, as the limitations on qui tam actions and a lack of interest on the part of the Justice Department drove the Act "into a period of desuetude." Evan Caminker, The Constitutionality of Qui Tam Actions, 99 YALE L.J. 341, 343 (1989); see also Elletta Sangrey Callahan \& Terry Morehead Dworkin, Do Good and Get Rich: Financial Incentives for Whistleblowing and the False Claims Act, 37 VIL. L. REV. 273, 318 (1992) (noting that, from 1943 to 1986, qui tam actions averaged about six per year and actions by the Attorney General averaged about ten per year); Pamela H. Bucy, Where to Turn in a Post-Punitive Damages World: The Qui Tam Provisions of the False Claims Act, 58 ALA. L.J. 356 (1997) (noting that "[f]or a variety of reasons, the FCA was not particularly effective until 1986").

Finally, in the midst of federal budget deficits and high-profile reports of fraud against the government, Congress amended the FCA in 1986. Gilles, supra note 2, at 1423; see also Michael Waldman, Time to Blow the Whistle? Qui Tam Lawsuits Are a Double-Edged Sword: They Encourage Disclosure of Fraud But Can Poison Workplace Relations, NAT'L L.J., Mar. 25, 1991, at 13 (noting that "[f]aced with well-publicized reports of $\$ 400$ hammers and $\$ 600$ toilet seats, Congress in 1986 turned to the whistleblower lawsuit as its chief weapon for fighting fraud"). The 1986 Amendments gave qui tam relators more power to imitiate and prosecute suits, enhanced financial incentives, and provided protection against employer retaliation. See generally $\$$ 3731(c), 3729(a)(7), 3730(d)(1)-(2). The 1986 Amendments also expanded the rights and role of the qui tam relator, increasing the relator's share of the recovery to fifteen to twenty-five percent of the recovery if the government intervenes, and 
On May 26, 1995, Stevens filed a sealed complaint against the State of Vermont under the qui tam provisions of the FCA. ${ }^{107}$ These provisions authorize a private person, the relator, to bring a civil action "in the name of the Government," against "[a]ny person" who "knowingly presents ... to ... the ... Government ... a false or fraudulent claim for repayment," and to receive a portion of the recovery in a successful action. ${ }^{108}$ After having received Stevens' complaint under seal, the Justice Department elected not to intervene in the FCA action, ${ }^{109}$ thereby allowing the relator to prosecute the action on his own. ${ }^{110}$ On November 7, 1996, Stevens, exercising his right under the FCA, served the complaint on the State of Vernont, and began prosecuting the lawsuit he filed. ${ }^{11}$

After the complaint was unsealed and served upon Vermont, the state moved to dismiss on Eleventh Amendment grounds. ${ }^{112}$ The district court denied the motion, ${ }^{113}$ and a divided panel of the Second Circuit affirmed. ${ }^{114}$

to twenty-five to thirty percent if it does not. $\$ 3730$; see also Steve France, The Private War on Pentagon Fraud, 76 A.B.A. J. 46, 47 (Mar. 1990). Finally, the 1986 Amendments increased the maximum damage award possible to three times the government damage (treble damages), and provided that attomey's fees could be required from the losing defendant. See Marc S. Raspanti \& David M. Laigaie, Current Practice and Procedure Under the Whistleblowing Provisions of the Federal False Claims Act, 71 TEMP. L. REv. 23, 27 (1998).

107. United States ex rel. Stevens v. Vt. Agency of Natural Res., 162 F.3d 195, 199 (2d Cir. 1998), rev'd, 120 S. Ct. 1858 (2000).

108. $\$ 3729(\mathrm{a})$.

109. Stevens, $120 \mathrm{~S}$. Ct. at 1861 . The qui tam relator is required to file his complaint in camera and under seal, and to serve these first on the Attorney General and on the local U. S. Attorney. $\S 3730(\mathrm{~b})(2)$. The complaint must remain under seal for at least 60 days, a period that may be extendcd by leave of the court, while government attorneys investigate the complaint's allegations. $\$ 3730$ (b)(2), (3). By the end of that sixty-day period (and any extensions) the Attorney General must inform the district court whether government attorneys will take over the action. $\S 3730(4)$.

In Stevens, the Attomey General elected not to take over prosecution of the action; however, she also chose not to intervene, as was her statutory right, to terminate the suit. Instead, she expressly reserved her statutory right to intervene against the State at a later time as the case proceeded. 162 F.3d at 199.

110. See $\S 3730(b)(4)(B)$. If government attorneys do take over the case, they "have the primary responsibility for prosecuting the action," and they may, subject to court approval, dismiss it altogether "notwithstanding the objections of the [relator]." $\$ 3730(c)(1),(2)$. If the Attorney General elects not to take over the case, on the other hand, the relator may prosecute the action in the name of the United States, but he must do so at his own expense and may become liable for the defendant's attomey's fees and expenses if the suit later is found by the court to be frivolous or vexatious. $\S 3730$ (c)(3), (d)(4), (f). Moreover, the Attomey General still retains the right to intervene and litigate the action upon "a showing of good cause." $\S 3730$ (c)(3). A portion of any recovery by the United States, whether or not the Attorney General elected to take over the litigation, must be shared with the relator. $\S 3730$ (d).

111. Stevens, $120 \mathrm{~S}$. Ct. at 1861.

112. The State argued in its motion that it was not a "person" withm the meaning of the FCA, such that the imposition of FCA liability on the States would violate the Eleventh Amendment. The Eleventh Amendment provides that the "Judicial Power of the United States shall not ... extend to any suit in law or equity, cornmenced or prosecuted against one of the United States by Citizens of another State ...." U.S. CoNSr. amend. Xl.

113. United States ex rel. Stevens v. Vt. Agency of Natural Res., No. 1:95-CV-161S (D. Vt. May 9, 1997) (order denying motion to disımiss). The district court rejected the state's contention that the FCA does not make states "person[s]" who are subject to liability under the Act. Id. In particular, the 
The state appealed to the Supreme Court, which granted certiorari to consider the two related issues of whether states were "persons" within the meaning of the FCA, and whether Eleventh Amendment immunity barred a private person from bringing a qui tam action agaimst a state under the statute. ${ }^{115}$ Vermont's decision to pursue this appeal was well-timed for three reasons: (1) the Court had recently decided a nuniber of Eleventh Amendment cases im favor of state immunity; ${ }^{116}$ (2) a circuit split on the

court noted that States have long considered themselves "persons" within the meaning of the Act in order to bring suits as qui tam plaintiffs. The court also rejected the state's claim of Eleventh Amendment immunity on the ground that the Amendment does not bar suits against the states by the Umited States itself, finding that the United States "is the real party in interest and ultimately the primary beneficiary of a successful qui tam action." Id.

114. United States ex rel. Stevens v. Vt. Agency of Natural Res., 162 F.3d 195 (2d Cir. 1998), rev'd, 120 S. Ct. 1858 (2000). The court of appeals, after a careful review of the provisions of the FCA, found that the United States retaims sufficient control over qui tam litigation to be considered the "real party of interest." For example, the court noted that the FCA provides that a qui tam action may be brought "for the person and for the United States Government. The action shall be brought in the name of the Government." $\$ 3730(\mathrm{~b})(1)$. Further, the United States is given an opportunity to intervene and take control of any qui tam action at the outset of hitigation. $\$ 3730(\mathrm{~b})(2)$. Even if the government elects not to intervene at the outset, it may intervene upon a showing of good cause at any time thereafter. $\$ 3730$ (c)(3). The court also noted that where the government intervenes, it takes control of the suit and has "primary responsibility for prosecuting the action." $\$ 3730$ (c)(I). In this scenario, the qui tam relator is allowed to continue to participate in the action, though the government may seek to severely limit the relator's role. $\$ 3730(\mathrm{c})(2)(\mathrm{C})$, (D). Moreover, the government has substantial authority to terminate the suit, even over the objection of the qui tam relator. $\$ 3730(\mathrm{c})(2)(\mathrm{B})$. Finally, the court considered situations in which the government chooses not to intervene, so that the relator has "the right to conduct the action." $\$ 3730(\mathrm{~b})(4)(B)$. The court found that even there, the government retains significant control over the action. For example, no other person may intervene in the action. $\$ 3730(\mathrm{~b})(5)$. The government is entitled to monitor the proceedmgs; it is entitled to have discovery stayed if discovery would interfere with its investigation or prosecution of a criminal or civil suit arising out of the same facts; it retains the right to intervene at any time for good cause, and the qui tam "action may be dismissed ouly if the court and the Attomey General give written consent to the dismissal and their reasons for consenting." $\$ 3730(b)(1)$, (c)(3), (4). Most persuasively, any recovery in a qui tam action, whether or not the government uitervenes, belongs principally to the United States, with the relator taking a percentage depending on various factors. $\S 3730$ (d)(1). Therefore, the court found that the Eleventh Amendment was no bar to liabihty in hitigation brought on behalf of the federal government. Stevens, 162 F.3d at 201-03.

Judge Jack Weinstein, U.S. District Judge for the Eastern District of New York, sitting by designation, dissented. Id. at 208-33.

115. Vt. Agency of Natural Res. v. United States ex rel. Stevens, 527 U.S. 1034 (1999).

116. See, e.g., Seminole Tribe v. Florida, 517 U.S. 44 (1996) (holding that Congress does not have the power under the Indian Commerce Clause to abrogate states' Eleventh Amendment immunity); Idaho v. Coeur d'Alene Tribe, 521 U.S. 261 (1997) (holding that an Indian tribe is barred by the Eleventh Amendment from seeking injunctive rehef in federal court in a suit to establish title to land); Coll. Savings Bank v. Fla. Prepaid Postsecondary Educ. Expense Bd., 527 U.S. 627 (1999) (holding that the federal Patent and Plant Variety Protection Remedy Clarification Act does not abrogate the protection of the Eleventh Amendment); Alden v. Maine, 527 U.S. 706 (1999) (holding that Congress does not have any greater power to subject a state to suit under federal law in state court than in federal court, and that the Eleventh Amendment bars suit in state court under the Fair Labor Standards Act); Kimel v. Fla. Bd. of Regents, 120 S. Ct. 631 (2000) (holding that the Age Discrimination in Employment Act of 1967 is not "appropriate legislation" under Section 5 of the Fourteenth Amendment, and thus Congress cannot abrogate states' Eleventh Amendment Immunity under the Act). 
issue of whether states were "persons" subject to liability under the FCA had begun to form; ${ }^{117}$ and (3) Vermont had the powerful support of virtually every state, state agency, major industry, health care provider, and other potential qui tam defendant interested in limiting the force of "whistleblower" suits. ${ }^{118}$ The state seemed destined to prevail on at least one of the two opposing fronts it had raised before the Court.

\section{B. The Supreme Court's Spontaneous Request}

When the case was argued before the Supreme Court in November 1999,119 however, something strange but not altogether unexpected happened. After extensive briefing and argument on the Eleventh Amendment immunity question and on the issue of whether states were persons under the FCA, the Court sua sponte directed the parties to file supplemental briefs addressing the question of whether a private person has standing under Article $1 \mathrm{II}$ to litigate claims of fraud upon the government. ${ }^{120}$

This was a remarkable turn for several reasons. First, every lower federal court confronted with this issue had determined that the qui tam relator has standing under Article III. ${ }^{121}$ While the Fifth Circuit had recently held the qui tam provisions of the FCA unconstitutional, its decision rested on Article II, rather than Article III grounds. ${ }^{122}$ The consistency with

117. United States ex rel. Long v. SCS Bus. \& Technical Inst., 173 F.3d 870, 882 (D.C. Cir. 1999) (finding that states are not "persons" under the FCA); United States ex rel. Foulds v. Tex. Tcch. Univ., 171 F.3d 279, 281 (5th Cir. 1999) (holding that the Eleventh Amendment bars qui tam actions against states); Zissler v. Regents of Univ. of Minn., 154 F.3d 870, 874 (8th Cir. 1998) (finding that states are "persons" under the FCA); United States ex rel. Graber v. City of New York, 8 F. Supp. 2d 343, 351 (S.D.N.Y. 1998) (finding that states are not "persons" under the FCA).

118. For example, amicus briefs were filed on hehalf of the state by the American Medical Association, Brief of Amici Curiae American Medical Association, Stevens, (No. 98-1828); the Aerospace Industries Association of America, Brief of Amici Curiae Aerospace Industries Association of America Stevens, (No. 98-1828); and the Umited States Chamber of Commerce, Brief of Amici Curiae United States Chamber of Commerce, Stevens, (No. 98-1828).

119. False Claims Act: Qui Tam Provisions in False Claims Act Under Scrutiny, U.S. L.WK. DAlly EdrTion, Dec. 3, 1999 (reporting on oral argument of case before Supreme Court).

120. Journal of Proceedings: November 1, 1999 Through November 29, 1999, U.S. L. WK. Daily EdrTion, Dec. 1, 1999 (reporting that on Novcmber 19, 1999, the Supreme Court issued an order in Stevens, directing the parties to "file supplemental briefs addressing the following question: 'Does a private person have standing under Article 111 to litigate claims of fraud upon the government?'").

121. See, e.g., United States ex rel. Rodgers v. Arkansas, 154 F.3d 865, 868 (8th Cir. 1998); United States ex rel. Berge v. Bd. of Trs. of the Univ. of Alabama, 104 F.3d 1453, 1458 (4th Cir. 1997); United States ex rel. Taxpayers Against Fraud v. Gen. Elec. Co., 41 F.3d 1032, 1041 (6th Cir. 1994); United States ex rel. Kelly v. Boeing Co., 119 F.3d 743, 748 (9th Cir. 1993); United States ex rel. Kreindler \& Kreindler v. United Tech. Corp., 985 F.2d 1148, 1155 (2d Cir. 1993); United States $e x$ rel. Chandler v. Hektoen Med. Research, 35 F. Supp. 2d 1078, 1079-81 (N.D. 11. 1999); United States ex rel. Truong v. Northrop Corp., 728 F. Supp. 615, 621-22 (C.D. Cal. 1989); United States ex rel. Stillwell v. Hughes Helicopters, Inc., 714 F. Supp. 1084, 1090-92 (C.D. Cal. 1989).

122. In Riley v. St. Luke's Episcopal Hospital, 196 F.3d 514, 523-24 (5th Cir. 1998), defendants argued that qui tam actions in which the government elects not to intervene violate the Take Care 
which the federal courts had addressed the Article III standing issue is likely the reason that Vermont never raised the issue of relator standing below. Second, as discussed in Part I, much of the current Court's standing jurisprudence had served to limit access to private citizens seeking to vindicate broader injuries. ${ }^{123}$ Therefore, the Court's spontaneous request for briefing on this issue caused many observers to wonder whether qui tam relators would be dealt the same Article III blows as the plaimtiffs in Lyons and Lujan. ${ }^{124}$ Finally, standing seemed utterly unrelated to the issues that Vermont and its formidable supporters had been pursuing for two years, namely, whether a state is a "person" within the meaning of the FCA and whether states have Eleventh Amendinent immuinty under the FCA. Rather than focusing on the sovereign status of the defendant, as the state had urged, the Court's request shifted the focus to the private citizen status of the plaintiff.

\section{The Court's Ruling on Relator Standing}

In an unexpected move, the Stevens Court upheld the standing of qui tam relators, announcing a new theory of "representational standing" whereby the standing of the United States to enforce federal laws may, under certain circumstances, be conferred upon a private actor as the "agent" or "assignee" of the government and its claims. ${ }^{125}$ After reviewing the now-familiar constitutional troika of imjury-in-fact, causation, and redressability, the Stevens Court emphasized the injury-in-fact prong and found it "beyond doubt that the [relator's] complaint asserts an imjury to the

Clause and the separation of powers doctrine because these provisions "stripped" the executive branch of its prosecutorial power. The Fifth Circuit agreed with the defendants that the qui tam provisions reduced the executive branch's control over litigation brought in the government's name, and further found that qui tam actions in which the government does not intervene encroach upon "the prosecutorial discretion that is at the lieart of the President's power to execute the laws." Id. at 525-26. Specifically, it found that the qui tam provisions did not give the Attomey General the power to remove the relator, control the decision to bring suit, deternine the scope of the suit once initiated, and that the relator was not bound to follow Department of Justice guidelines. Id. at 528. The Fifth Circuit was particularly concerned by qui tam actions in which the government elected not to intervene, explaining that where "the sole injury-the only ticket into court-belongs to the government, the Executive's prosecutorial discretion must include the power to decide whether to bring suit." Id. at 526. Thus, according to the court, an mdividual's suit on behalf of the government that is permitted to proceed despite the government's decision not to intervene encroaches on the executive's discretion over whether to prosecute a claim in violation of the constitution. Id.

123. See supra text accompanying notes 67-98 (discussing the current Court's constitutionalization of standing doctrine).

124. See Charles Tiefer, Surprise Order in Qui Tam Case May Foretell a Scalia Surprise, LEGAL TIMES, Nov. 29, 1999, at 52. In addition, the Court had refused to address the constitutionality of the qui tam provisions in Hughes Aircraft Co. v. United States ex rel. Schumer, 517 U.S. 1218 (1996). In Schumer, the Court went so far as to invite the Solicitor General to file a brief expressing the United States' views on qui tam. However, when the Court finally decided to hear Schumer, it declined certiorari on the constitutional issues in the case. Id.

125. Vernont Agency of Natural Res. v. United States ex rel. Stevens, 120 S. Ct. 1858, 1863 (2000). 
United States."126 Distinguishing between injuries to the government in its sovereign and proprietary capacities, the Court explained that the relator alleged that the government had suffered both a sovereign injury, in that federal law was violated, and a proprietary injury, in that it had made payments on false claims. ${ }^{127}$ The Court's distinction between sovereign and proprietary injuries suffered by the government is significant because the core concept of representational standing requires an understanding of when and why a private litigant may be allowed to bring suit to remedy one or the other form of governmental injury. ${ }^{128}$

Having determined that the United States had suffered the requisite injury to trigger federal jurisdiction, the Court then considered whether the relator had standing to bring suit to remedy that injury. ${ }^{129}$ First, the Court raised the possibility of relator standing based on an agency theory: "It would perhaps suffice to say that the relator here is simply the statutorily designated agent of the United States, in whose name...t the suit is brought." ${ }^{\prime 130}$ If the agency theory were valid, the Court posited, the bounty received by a successful relator would be akin to a fee for prosecuting the action..$^{131}$ The presence of such a fee would suffice to satisfy the Article III standing requirements.

The agency theory was precluded, however, by the Court's determination that the statute "gives the relator himself an interest in the lawsuit, and not merely the right to retain a fee out of the recovery." ${ }^{132}$ For example, the relator has the right to continue as a party to the action even where the government intervenes; ${ }^{133}$ the relator is entitled to a hearing before the government may dismiss a qui tam suit; ${ }^{134}$ and the government may not settle the suit over the relator's objection without a hearing on the fairness and adequacy of the proposed settlement. ${ }^{135}$ Thus, the specific statutory structure of the qui tam provisions of the FCA, by giving the relator rights

126. Id. at $1861-62$.

127. Id. at 1862 .

128. See infra Part IV (discussing the role of private litigants as either assignees or agents of governmental authority).

129. Stevens, $120 \mathrm{~S}$. Ct. at 1862-63. Interestingly, rather than applying its strict, constitutional standing analysis, the Stevens Court appeared to retum to the more liberal standing inquiry of the Warren Court era. For example, rather than asking whether the relator had suffered the requisite "irnminent" injury-in-fact, the Court instead noted that "the bounty [the relator] will receive if the suit is successful," establishes that a qui tam relator has a "concrete private interest in the outcome of [the] suit." Id. at 1862 (citing Lujan v. Defenders of Wildlife, 505 U.S. 555, 573 (1992)). The "concrete private interest" standard is strikingly similar to the Baker/Flast "adverseness" standard. See supra text accompanying notes $21-41$ (discussing the Warren Court's application of flexible, prudential standards in determining standing of citizen-voters and taxpayers).

130. Stevens, 120 S. Ct. at 1862.

131. Id.

132. Id.

133. Id. (citing 31 U.S.C. $\$ 3730(c)(1)$ (1994)).

134. Id. (citing $\$ 3730(\mathrm{c})(2)(\mathrm{A})$ ).

135. Id. (citing $\$ 3730(\mathrm{c})(2)(\mathrm{B})$ ). 
independent and perhaps even at odds with the government, precluded the application of an agency theory of standing in this context. According to the Court, "the portion of recovery retained by the relator" required an explanation other than agency on behalf of the government. ${ }^{136}$

The Court found such an explanation in "the doctrine that the assignee of a claim has standing to assert the injury in fact suffered by the assignor." 137 In finding that the FCA "can reasonably be regarded as effecting a partial assignment of the Government's damages claim," the Court noted that although it had "never expressly recognized 'representational standing' on the part of assignees" it had "routinely entertained their suits" in various private law contexts. ${ }^{138}$ The Court correctly characterized the FCA as creating a partial assignment because under the statute, the government retains the right to intervene in the qui tain action, and may move to dismiss or attempt to settle the suit over the objections of the relator. A full assignment would leave the government no continuing interest in the assigned claim. The Court thus concluded that "the United States' injury in fact suffices to confer standing" on the qui tam relator under an assignment theory. ${ }^{139}$

The Court confirmed its conclusion by reciting the long tradition of qui tam actions in Anglo-American law. ${ }^{140}$ Tracing the ebb and flow of qui tam statutes in England from the thirteenth and fourteenth centuries, ${ }^{141}$ through to the era of Parliamentary rule, ${ }^{142}$ the Court noted that the English informer statutes "expressly gave the informer a cause of action, typically by bill, plaint, information, or action of debt."143 Similarly, according to the

136. Id.

137. Id. at 1863. The Court's acceptance of the assignment theory confirms the decisions of various lower federal courts upholding relator standing on similar grounds. See, e.g., United States $e x$ rel. Kelly v. Boeing Co., 119 F.3d 743, 748 (9th Cir. 1993); United States ex rel. Milam v. Univ. of Tex. M.D. Anderson Cancer Ctr., 961 F.2d 46, 49 (4th Cir. 1992).

138. Stevens, 120 S. Ct. at 1863 (citing Poller v. Columbia Broad. Sys., Inc., 368 U.S. 464, 465 (1962); Automatic Radio Mfg. Co. v. Hazeltine Research, Inc., 339 U.S. 827, 829 (1950); Hubbard v. Tod, 171 U.S. 474, 475 (1898)).

139. Id. at 1863 .

140. Id. at 1863-65. Of course, the Court's recitation of the historical pedigree of qui tam actions may itself have been the driving force behind the grant of standing in this case. In other words, even Justice Scaha may have cringed at the thought of overturning six centuries of jurisprudence upholding the right of relators to bring suit on behalf of the government. See, e.g., United States of America ex rel. Rudd v. Gen. Contractors, Inc., Nos. C-89-397-RJM, C-89-821-RJM (E.D. Wash. Dec. 4, 1990) (order denying inotion to dismiss) (citing Martin v. Trout, 199 U.S. 212, 225 (1905)) ("[T]he concept of qui tam is so deeply rooted in the nation's Inistory that it is most improbable that any court today could divine sone infirmity of constitutional nagnitude which would not have been equally apparent many decades, if not centuries, ago.").

141. Stevens, 120 S.Ct. at 1863 , citing Prior of Lewes v. De Holt (1300), reprinted in 48 SELDEN SocIety 198 (1931); 2 W. Hawkins, Pleas of THE CROWN 369 (8th ed. 1824).

142. Id., citing Statute Providing a Remedy for Him Who Is Wrongfully Pursued in the Court of Admiralty, 1400, 2 Hen. 4, c. 11 (Eng.), Statute Prohibiting the Sale of Wares After the Close of Fair, 1331,5 Edw. 3, c. 5 (Eng.).

143. Id. at 1864. 
Court, qui tam provisions appear to have been as prevalent in Early America as in England, as the colonies enacted several informer statutes immediately before the framing of the Constitution. ${ }^{144}$ Moreover, immediately after the framing, the First Congress enacted a considerable number of informer statutes, ${ }^{145}$ inany of which provided both a bounty and an express cause of action. ${ }^{146}$ Accordingly, this historical backdrop, "combined with the theoretical justification for relator standing" based on the government's partial assignment of its claim, was "well nigh conclusive" of the standing inquiry presented in Stevens. ${ }^{147}$

The standing decision of Stevens holds immense potential for legislators seeking to vest standing in private actors seeking to bring suit to vindicate broad public interests. For the first time since the constitutionalized standing doctrine reached its zenith in Lyons and Lujan, ${ }^{148}$ the Stevens decision suggests that "the traditional requirement that the plaintiff's alleged injury be a particularized one, which sets him apart from the citizenry at large, ${ }^{\prime 149}$ does not preclude Congress from vesting in individuals "representational standing" to pursue claims they would otherwise lack standing to assert. The next Part, therefore, considers the theory of representational standing, with a view towards the theoretical and practical significance of this new doctrine for the future of public law litigation.

144. Id., citing Act for the Restraining and Punishing of Privateers and Pirates, 1st Assemb., 4th Sess. (N.Y. 1692), reprinted in 1 CoLONIAL LAws OF NEW YORK 279, 281 (1894) (allowing informers to sue for, and receive share of, fine imposed upon officers who neglect their duty to pursue privateers and pirates).

145. Id. at 1864 n.5 (noting that the First Congress also passed one statute allowing injured parties to sue for damages on both their own and the United States' behalf. See Act of May 31, 1790, ch. 15, \$ 2, 1 Stat. 124, 124-25 (repealed 1802) (allowing author or proprietor to sue for and receive half of penalty for violation of copyright)); cf. Act of Mar. 1, 1790, ch. 2, §6, 1 Stat. 101, 103 (repealed 1795) (allowing census taker to sue for and receive half of penalty for failure to cooperate in census); Act of July 5, 1790, ch. 25, §1, 1 Stat. 129 (obsolete) (extending same to Rhode Island)).

146. Id. at 1864 n.6, citing Act of Mar. 1, 1790, ch. 2, § 3, 1 Stat. 101, 102 (repealed 1795) (allowing informer to sue for, and receive half of fine for, failure to file census return); Act of July 5 , 1790, ch. 25, § 1, 1 Stat. 129 (obsolete) (extending same to Rhode Island); Act of July 20, 1790, ch. 29, $\S \S 1,4,1$ Stat. 131, 133 (allowing private individual to sue for, and receive half of fine for, carriage of seamen without contract or illegal harboring of runaway seamen); Act of July 22, 1790, ch. 33, $\$ 3,1$ Stat. 137, 138 (repealed 1793) (allowing private individual to sue for, and receive half of goods forfeited for, unlicensed trading with Indian tribes); Act of Mar. 3, 1791, ch. 15, § 44, 1 Stat. 209 (allowing person who discovers violation of spirits duties, or officer who seizes contraband spirits, to sue for and receive half of penalty and forfeiture, along with costs, in action of debt); cf. Act of Apr. 30 , 1790 , ch. $9, \S \S 16,17,1$ Stat. 116 (allowing informer to conduct prosecution, and receive half of fine, for criminal larceny or receipt of stolen goods).

147. Id. at 1865.

148. See supra text acconpanying notes 69-94 (discussing the application of the Court's increasingly restrictive constitutional standing rules in Lyons and Lujan).

149. Scalia, supra note 15, at 881-82. 
III

\section{An ANALysis of "Representational Standing"}

Narrowly read, the Stevens Court's recognition of "representational standing" saved the qui tam provisions of the FCA from constitutional infirmity on Article III grounds. However, a broader reading of the case suggests the development of a portentous new doctrine in Article III jurisprudence. Properly understood, the "representational standing" doctrine of Stevens einpowers the legislative branch, under appropriate circumstances, to revive the popular forces that powered the great civil rights, environmental and other public law movements of the twentieth century, but which have appeared unavailable in the wake of the Court's constitutionalization of standing doctrine. ${ }^{150}$

The key question, therefore, is under what circumstances will representational standing pass constitutional muster? To answer this question, it is necessary to explore the contours of the assignment theory relied upon in Stevens, and the potential of the broader theory of agency that the Court found inapphicable under the facts of that case.

\section{A. The Assignment Theory}

The Stevens Court ultimately held that a qui tam relator is properly considered a partial "assignee" of the government's injuries and claims under the FCA. Thus, the relator need not suffer his own injury, but may be statutorily assigned the government's injury in order to bring suit on a claim under the FCA. The Court's reasoning on the assignment theory raises a number of interesting questions, including: (1) Is assignment available only where the government is acting in its proprietary capacity, as it is in the FCA context? and (2) What are the practical and constitutional implications of partial assignment as opposed to full assignment of a claim by the government?

\section{The Distinction Between Proprietary and Sovereign Injury}

The Court in Stevens observed that in the context of the FCA, the government suffers two distinct types of injury: "the injury to its sovereignty arising from violation of its laws (which suffices to support a criminal lawsuit by the Government) and the proprietary injury resulting from the alleged fraud." 151 While the Court did not explore this observation in any depth, careful consideration reveals that the distinction between proprietary and sovereign injuries lies at the very core of the representational standing concept and, indeed, is the primary differentiator between

150. See infra Part IV (discussing potential applications of assignment and agency theories of representational standing).

151. Stevens, $120 \mathrm{~S}$. Ct. at 1862. 
the two sub-species of representational standing articulated in the Stevens decision.

It seems safe to say that assignment may form the basis of representational standing only where the government's claim seeks to vindicate a proprietary injury. ${ }^{152}$ The explanation lies in the private law heritage of the assignment doctrine that the Stevens Court applied in the public law context. ${ }^{153}$ In traditional private law applications of assignment, only property rights and the concomitant power to bring suit to enforce those rights are assignable; $;^{154}$ the right to enforce liberty or other non-monetary interests is not. ${ }^{155}$ Indeed, the traditional rule is that causes of action are assignable

152. The govemment can only suffer such injuries when it is acting in a non-governmental capacity; in other words, when the government suffers a proprietary injury, it is acting more as a private actor than as a governmental entity. In these circumstances, Congress may partially assign to a private citizen the right to pursue the claim, with payment to be carved out of any successful recovery. Thus, rather than bring an action itself to recover financial loss, the govemment, acting more like a private entity, may assign a portion of its claim to a party willing to undertake the effort and expense to recover the assigned portion of the proceeds. But see Caminker, supra note 106, at 349-50 (arguing that the qui tam provisions of the FCA reflect 'the understanding that the United States, as 'sovereign,' represents the interests of the public at large. Through litigation, the United States attempts to redress the public injuries created by false claims practices, both by recouping siphoned treasury funds and by deterring future threats to economic and national security.").

153. Indeed, the cases cited by the Stevens Court in support of the assignment theory of relator standing all involve private, contractual assignments of propertied or proprietary claims. See Poller v. Columbia Broad. Sys., Inc., 368 U.S. 464 (1962); Automatic Radio Mfg. Co. v. Hazeltine Research, Inc., 339 U.S. 827 (1950); Hubbard v. Tod, 171 U.S. 474 (1898); see also John M. Limbaugh, The Sacrificial Attorney: Assignment of Legal Malpractice Claims, 65 Mo. L. Rev. 279, 281 (2000) (noting that while "at early common law, no cause of action or chose in action was assignable," equity courts građually allowed "assigunent of choses in action arising out of contract," and "the assignment of choses in action arising out of torts to real or personal property").

154. Of course, property is not limited to the eategory of tangible things; individuals may also possess property rights in their ideas and other intangible assets. Thus, patents, trademarks and copyrights, and the concomitant right to sue for the enforcement of those interests, are generally assignable. See 35 U.S.C. $\$ 261$ (providing that patents have the attributes of personal property, and can be assigned, mortgaged, and devised like any other personal property, so long as the assignment is in writing); see also Kristine Boylan, The Corporate Right of Publicity in Federal Dilution Legislation, 82 J. Pat. \& TRADEMaRK OFF. Soc'y 5, 9 (2000) (noting that courts have stated that there "might be protection of property in trademark law, and consequently, permitted assigninents of tradenarks just as an ownership interest in a piece of real or personal property would be assigned").

155. See, e.g., In re Magness, 972 F.2d 689, 695-96 (6th Cir. 1992) (denying assignment of country club membership because of personal nature of interest); Haelan Labs., Inc. v. Topps Chewing Gum, Inc., 202 F.2d 866, 868 (2d Cir. 1953) (observing that baseball player who granted to chewing gnm manufacturer right to use his photograph in sales materials has right of privacy, "i.e., a personal and non-assignable right not to have [one's] feelings hurt'); In re Taylor Mfg., 6 B.R. 370, 372 (Bankr. N.D. Ga. 1980) (providing example of inequity created in assignment of personal services contract by forcing promoter to accept performance from assignee rather than opera singer with whoin he contracted); Archer v. Archer, 493 A.2d 1074, 1080 (Md. Ct. App. 1985) (finding that a medical degree or license does not constitute marital property within the ambit of its equitable distribution statute because it was "but an intellectual attainment ... not a present property interest. It is personal to the holder; it cannot be sold, transferred, pledged or inherited. It does not have an assignable value nor does it represent a guarantee of receipt of a set of monetary amount in the future, such as pension benefits"). Indeed, even in the private law context, contracts may expressly state that certain proprietary claims are to be considered "personal" and thus not assignable. So, for example, a landlord may draft a lease in 
only if they would survive the death of the putative assignor. ${ }^{156}$ Thus, since the time of Pomeroy, assignable claims have been understood to include "all claims arising from contracts express or implied, with certain well-defined exceptions, and those arising from torts to real or personal property, and from frauds, deceits, and other wrongs whereby an estate, real or personal, is injured, diminished, or damaged." 157 In modern practice, courts have reduced Pomeroy's formulation to a shorthand, uniformly ruling that claims whicl are inherently "personal," sucl as child custody, personal injury, marital, or false imprisonment claims, are not assignable, ${ }^{158}$ while claims vindicating traditional proprietary interests may be assigned. ${ }^{159}$

Upon consideration, it appears that the "personal" vs. "proprietary" fault-line developed in the private law context remains intact when applied to the public law context, dividing the landscape imto "sovereign" and

which an option to extend the term of a lease is personal to the original tenant and therefore not available to an assignee or subtenant. While the option is clearly a proprietary element, the landlord is permitted to characterize it as personal so as to limit obligations to third parties.

156. See, e.g., Beall v. Farmers' Exch. Bank, 76 S.W.2d 1098, 1099 (Mo. 1934); Prop. Exch. \& Sales, Inc. v. Bozarth, 778 S.W.2d 1, 2 n.1 (Mo. Ct. App. 1989). An exception to this general rule is that while personal injury actions survive, they are not assignable. See Beall, 76 S.W.2d at 1099; Bozarth, 778 S.W.2d at 2 n.1; Forsthove v. Hardware Dealers Mut. Fire Ins. Co., 416 S.W.2d 208, 217 (Mo. Ct. App. 1967); see also Eastem Atl. Transp. \& Mecl.. Eng'g, Inc. v. Dingman, 727 S.W.2d 418, 423 (Mo. Ct. App. 1987) (holding that a tort claim is assignable to the extent that it provides the basis for an award of exemplary damages in an otherwise assignable action for breach of contract); Nat'l Union Fire Ins. Co. of Pittsburgh, Pa. v. KPMG Peat Marwick, 742 So. $2 d 328$ (Fla. Dist. Ct. App. 1999) (holding that, under Florida law, the prohibition against assignment of personal claims did not bar a fidelity insurer's claim, either as assignee or subrogee, against its insured's imdependent auditors).

157. 3 John Norton Pomeroy, EQUITY JuRISPRudence $\$ 1275$ (Spencer Symons ed., 5th ed. 1941); see also Atl. \& N.C. R.R. Co. v. Atl. \& N.C. Co., 61 S.E. 185 (N.C. 1908).

158. See Francis M. Dougherty, Assignability of Claims for Legal Malpractice, 40 A.L.R. 4th 684 (1995) (stating that the only causes of action whicl are non-assignable "are those for torts for personal injuries and for wrongs done to the person, the reputation, or the feelings of an injured party, and those for breach of contract of a purely personal nature, such as promises of marriages"); see also 6 AM. JUR. $2 d$ Assignments $\S 39$ (1963) (stating that "[i]n some jurisdictions it is leld that a right of action for personal injuries is not assignable"); David M. Kono, Unraveling the Lining of ERISA Health Insurer Pockets-A Vote for National Federal Common Law Adoption of the Make Whole Doctrine, 2000 B.Y.U. L. REv. 427, 429 (2000) (discussing cases disfavoring the assignment of personal injury claims and the judicial efficiency policy of prohibiting the division of a cause of action).

159. Interestingly, however, some courts have aecepted the assignment of legal or medical malpractice claims. See, e.g., Hedlund Mfg. Co. v. Weiser, Stapler \& Spivak, 539 A.2d 357 (Pa. 1988); Ammon v. McCloskey, 655 A.2d 549 (Pa. Super. Ct. 1995) (finding that a personal injury claimant's malpractice clainn may be assigned to an adversary as part of a resolution of the personal injury lawsuit). While such claims appear personal rather than proprietary, one commentator lias noted that where "a legal malpractice claim may be transferred by assignment or subrogation, its value to a client is enhanced because a client may realize benefit from the malpractice without taking the risk, time and expense of litigating that claim." Jeffrey Albert, A Consumer-Eye View of Pennsylvania Legal Practice: Leaming from Our Mistakes, 71 PA. B. Ass'N Q. 70, 77 (2000). But see Dougherty, supra note 158, at 684 (arguing that the legal malpractice claim slould be non-assignable "because of the personal relationship which exists between an attoruey and his client ... [whicli] likened an action for legal malpractice to actions for torts involving personal injuries or wrongs done to the person"). 
"proprietary" interests. ${ }^{160}$ Just as assignability in the private law context hinges on the diminution of an estate, the government may assign the right to vindicate the proprietary injury it suffers where the federal treasury is diminished. Such claims look to compensate the government for the loss it directly suffers in its capacity as a proprietor, as the keeper of the public fisc and the owner of public property.

Sovereign interests, by contrast, implicate "injury... arising from violation of [the government's] laws," the paradigmatic example being criminal law. ${ }^{161}$ In keeping with the private law analogy, such injuries are "personal" to the government. Claims based on these sovereign injuries do not, in any direct sense, seek to redress diminution of the federal treasury. Even where such claims are directed at monetary damages, they do not directly seek to compensate the government for injury to its property. Under the traditional formulation of assignment, then, claims seeking to vindicate the government's non-proprietary, sovereign interests are not assignable.

Article II of the Constitution and separation of powers principles ${ }^{162}$ further suggest that claims brought to vindicate the government's proprietary interests may be assigned, while claims based on injury to the government's sovereign interests may not be assigned. Article II, section 3 vests in the President the sole power and duty to "take Care that the laws be faithfully executed."163 Congressional enactments which authorize private citizens to exercise powers exclusively reserved to the Executive in Article II potentially undermine the authority of the coordinate branch, raising serious separation of powers concerns. The government's "sovereign" interest in the enforcement of the federal laws is at the very heart of the Take Care Clause. By contrast, there is no constitutional

160. By the same token, courts have analogized from the traditional formulation of Pomeroy to hold that a corporation's claims are assignable where they would survive the dissolution of the corporate entity. See, e.g., Zimmerman v. Kyte, 765 P.2d 905 (Wash. Ct. App. 1988) (where a dissolved corporation assigned its right to sue its shareholders, and the shareholders filed suit against former employees of the corporation, shareholders have standing based on assignment).

161. Vermont Agency of Natural Res. v. United States ex rel. Stevens, 120 S. Ct. 1858, 1862 (2000).

162. Separation of powers is a function of the Constitution's basic structure, which "divides all power conferred upon the Federal Government into 'legislative Powers,' '[ $t]$ he executive Power,' and '[t]he judicial Power."' Lujan v. Defenders of Wildlife, 504 U.S. 555, 559 (1992).

163. U.S. CONST. art. II, $\$ 3$; see also U.S. CONST. art. II, $\$ 1$, cl. 1 ("The executive Power shall be vested in a President of the United States of America."). The President delegates authority in most of the civil and criminal suits brought on behalf of the federal government to the Attorney General, and "all such suits, so far as the interests of the United States are concerned, are subject to the direction, and are within the control of, the Attomey General." Buckley v. Valeo, 424 U.S. 1, 139 (1976); see also United States v. San Jacinto Tin Co., 125 U.S. 273, 279 (1888) (stating that the Attorney General is "undoubtedly the officer who has charge of the institution and conduct of the pleas of the United States, and of the litigation which is necessary to establish the rights of the government"); Springer v. Philippine Islands, 277 U.S. 189, 202 (1928) (stating that the Take Care Clause "gives the Executive the power to enforce the laws"). 
mandate that the government "take care" to maximize its proprietary interests. ${ }^{164}$

\section{Partial vs. Full Assignments of Proprietary Claims}

Just as assignment in the public law context is limited to claims seeking to vindicate the government's proprietary (as opposed to sovereign) interests, it may well be that only partial (as opposed to full) assignments are permissible under the theory rehed on in Stevens. The Stevens Court was very careful to state (albeit without explanation) that the qui tam relator is "a partial assignee of the United States."165 And the Court was correct to characterize the assignment as a partial one: where an assignor fully assigns a claim, he retains no interest in the assigned claim and lacks standing to sue. ${ }^{166}$ In the context of the FCA, by contrast, the government retains the right to intervene in the qui tam action, and may move to dismiss or atteinpt to settle the suit over the objections of the relator. ${ }^{167}$ The assignment in this context is thus classically "partial." 168

The distinction between partial and full assignment is potentially crucial in the public law context because separation of powers principles

164. See, e.g., United States ex rel. Truong v. Northrop Corp., 728 F. Supp. 615, 620 (C.D. Cal. 1989) ("In a False Claims action, the judicial branch is not called upon to create eauses of action or make any policy determinations. There is a concrete, identifiable claim for fraud against the government, the prosecution of which Congress, pursuant to its policymaking authority, has placed under the direction of the qui tam relator.").

165. Stevens, 120 S. Ct. at 1863 n. 4.

166. See, e.g., Lans v. Gateway 2000, Inc., 84 F. Supp. 2d 112, 123 (D.D.C. 1999) (holding that an assignor lacked standing to sue for infringement); Procter \& Gamble Co. v. Paragon Trade Brands, Inc., 917 F. Supp. 305, 312 n.11 (D. Del. 1995) (holding that assignors were not proper parties to a patent action because "[w] hen rights to a patent are effectively assigned, the assignor retains no further rights in that which was assigned and as a result has no stake in the outcome of the litigation"); Hertel v. Home Ins. Co., 604 P.2d 269 (Ariz. Ct. App. 1979) (holding that when the employee's claim was assigned to the carrier, no interest remained in the employee).

167. See supra note 114 and accompanying text.

168. As Thomas Lee has noted, objections lodged against partial assignments are generally concerned with preventing multiple suits on a simgle right of action. Lee, supra note 103, at 570. Lee argnes, however, that these objections fail to recognize two unique aspects of the assignment at issue in the FCA context:

The first is that the FCA preserves a single cause of action. Under the FCA, the Justice Department is entitled to intervene, and the federal government is entitled to share in the recovery, but the suit filed by the relator precludes a separate action by the government or anyone else. In this sense, the FCA's assignment is not partial. Rather, the government's right to intervene and share in the recovery are properly characterized as its 'fee' for the full assignment of the right of action.

Id. at 565. The second aspect of the FCA's assignment is that it is part of an Act of Congress. Even if some state laws forbid this kind of assignment, the FCA is federal law and therefore trumps state law under the Supremacy Clause. Congress clearly meant to confer standing on qui tam plaintiffs; it is mdisputably the intent and effect of the FCA to assign the government's cause of action, contingent on the qui tam relator's filing the suit.

Id.; see also 3 BLACKSTONE, supra note 106, at 162 (noting that the result in a qui tain suit "is a bar to all others, and [is] conclusive even to the king himself'). 
clearly prohibit Congress from creating a statutory scheme that "disrupts the proper balance between the coordinate branches [by] prevent[ing] the Executive Branch from accomplishing its constitutionally assigned functions." 169 It is likely that full assignment of proprietary claims by the government, under a legislative regime which prohibits the Executive from intervening or exercising any control over assigned claims, would violate separation of powers. ${ }^{170}$

While the vindication of the government's proprietary interests lies outside the province of functions that are exclusively committed to the Executive under the Take Care Clause, ${ }^{171}$ Congress's ability to assign private litigants the power to prosecute these interests is nonetheless subject to separation of powers principles. An extreme example illustrates this proposition: what if Congress purported to vest private litigants with the sole authority to sue under the FCA, such that the government itself, the injured party, ${ }^{172}$ had no right to vindicate its own proprietary interests? While such an assignment might not violate the Take Care Clause, it would certainly trigger separation of powers concerns about legislation "that undermine[s] the authority and independence of one or another coordinate branch."173

The constitutionality of a governmental assignment, then, will depend in part upon the level of control retained by the Executive. As the Supreme Court has made clear, ${ }^{174}$ congressional grants of executive functions to private litigants must preserve executive discretion to initiate, oversee, and terminate litigation. ${ }^{175}$ Within the universe of assignments, only partial assignments are capable of preserving these executive prerogatives; full

169. Morrison v. Olson, 487 U.S. 654, 695 (1988) (quoting Nixon v. Adm'r of Gen. Servs., 433 U.S. 425,443 (1977)).

170. This is not to suggest that the Executive may not effect a full assignment of its proprietary claims. The Take Care Clause has consistently been interpreted to limit only legislative efforts to divest the Executive of enforcement powers. See id.

171. See infra text accompanying notes 151-164 (discussing the proprietary vs. sovereign distinction).

172. See Vermont Agency of Natural Res. v. United States ex rel. Stevens, 120 S. Ct. 1858,1862 (2000). (noting that, in the false claims context, the government has suffered both proprietary and sovereign injury).

173. Mistretta v. United States, 488 U.S. 361, 382 (1989).

174. See generally Morrison, 487 U.S. 654.

175. For exainple, the Morrison Court found that an independent counsel can only be appointed by specific request of the Attorney General. Id. at 695 . The Attorney General's decision not to request appointment if she finds "no reasonable grounds to believe that further investigation is warranted" is unreviewable. Thus the Act "gives the Executive a degree of control over the power to initiate an investigation by the independent counsel." Id. at 696 . The Court also found that once an independent counsel is appointed, he must abide by Justice Department policy and have bis jurisdiction defined by the Attorney General. Id. Finally, the Morrison Court reasoned that the Attorney General retains the power to remove the independent counsel for "good cause," a power the Court found "provides the Executive with substantial ability to ensure that the laws are 'faithfully executed' by an independent counsel." Id. 
assignments, by their very nature, unconstitutionally infringe upon the Executive's discretion over litigation brought on its behalf. ${ }^{176}$

Indeed, the only court in the country to declare the qui tam provisions of the FCA unconstitutional did so on separation of powers grounds, interpreting the FCA as effecting a full assignment of the government's claim. ${ }^{177}$ The Fifth Circuit in Riley v. St. Luke's Episcopal Hospital ${ }^{178}$ found that qui tam actions in which the government elects not to intervene violate separation of powers doctrine because these provisions "strip" the Executive branch of the power to control the litigation. ${ }^{179}$ While the Stevens

176. The other Article II question raised by Congressional assignment involves the Appointments Clause, which requires that principal "Officers of the United States" be appointed by the President with the advice and consent of the Senate, and that inferior officers may, by congressional authorization, be appointed by the President, heads of departments or the judiciary. U.S. CoNST. art. II, $\$ 2$, cl. 2; see also Buckley v. Valeo, 424 U.S. 1, 132 (1976) ("[P]rincipal officers are selected by the President with the advice and consent of the Senate. Inferior officers Congress may allow to be appointed by the President alone, by the heads of departments, or by the Judiciary."). Here again, a set of determining criteria is supplied by Morrison, where the Court concluded that the independent counsel was an inferior officer within the meaning of the Apponitments Clause. 487 U.S. at 670-77. Applying a similar test for the Appointments Clause challenge as for the "take care" challenge, the Morrison Court first noted that the independent counsel is subject to removal by a higher executive branch official, which indicates that she is "to some degree 'inferior" in rank and authority." Id. at 671. Second, the Court found that the independent counsel's job is limited to the investigation and possible prosecution of certain federal crimes. Id. Finally, the Court noted that the independent counsel's job is a temporary one: "an independent counsel is appointed essentially to accounplish a single task, and when that task is over the office is terminated." Id. at 672. Lower federal courts have relied on the Morrison inquiry to determine whether qui tam relators are principal or inferior officers. These courts have uniforinly reasoned that qui tam relators are "inferior" or "subordinate" officers because they have a length of service that is generally limited to a single case, a relatively limited scope of authority, and are not vested with the "primary responsibility" for enforcing the FCA. See, e.g., United States ex rel. Truong v. Northrop Corp., 728 F. Supp. 615, 621-22 (C.D. Cal. 1989); United States ex rel. Stillwell v. Hughes Helicopters, Inc., 714 F. Supp. 1084, 1090-92 (C.D. Cal. 1989). Thus, as the assignment theory does not change this analysis, the Appointments Clause does not present a significant challenge.

177. Indeed, most lower federal courts confronted with this issue had deterinined that the qui tam provisions of the FCA did not violate Article II. See, e.g., United States ex rel. Newsham v. Lockheed Missiles \& Space Co., 772 F. Supp. 607, 615 (N.D. Cal. 1989) ("The qui tam provisions do not violate the separation of powers doctrine. The executive Branch retains sufficient control over the qui tam litigation so as to ensure that the President is able to perform his constitutionally assigned duties.").

178. 196 F.3d 514, 523 (5th Cir. 1999). The Fifth Circuit has granted an en banc rehearing in Riley, but a decision has not been rendered yet. 196 F.3d 1561 (5th Cir. 1999).

179. Riley, 196 F.3d at 525-26. Specifically, the defendants in Riley argued that the executive lacks control at the very initial stages of litigation because a qui tam relator can file a false claims action without the consent of the Attomey General. Id. at 523; see also 31 U.S.C. $\$ 3730(b)(1)$ (1994). Similarly, in the actual prosecution of the litigation, the government's "control"-for Morrison purposes-is undercut by the fact that a qui tam relator renıains, by operation of law, a party in interest, irrespective of whether the Justice Department elects to take over the lawsuit during the sixty-day sealing period. $\S 3730(\mathrm{~b})(4)(\mathrm{A})$. Finally, the Justice Department may not settle or otherwise terminate the litigation vithout the consent of the relator, unless it can prove to a court that the proposed settleinent is "fair, adequate and reasonable under all the circunistances." $\$ 3730$ (c)(2)(B). The Fifth Circuit agreed with the defendants that the qui tam provisions reduced the executive branch's control over hitigation brought in the government's name, and further found that qui tam actions in which the govemment does not intervene encroach upon "the prosecutorial discretion that is at the lreart of the President's power to execute the laws." Riley, 196 F.3d at 523. 
Court did not explicitly address separation of powers issues, it arguably pulled the rug out from under the Fifth Circuit by clarifying that the FCA effects partial, not full, assignment of the government's claims, since it preserves the Executive's right to intervene, move to dismiss or attempt to settle a qui tam action over the objections of the relator. ${ }^{180}$

It therefore appears that representational standing may be predicated upon assignment where (1) the assigned claim would vindicate the government's proprietary interests; and (2) the assignment is a partial one, such that the Executive retains sufficient control over the litigation to satisfy separation of powers principles.

\section{B. The Agency Theory}

Another potential basis for representational standing lies $\mathrm{m}$ the concept of agency. In Stevens, the Court considered whether "it would perhaps suffice to say that the relator ... is simply the statutorily designated agent of the United States."181 Under the particular statutory regime of the FCA, however, the Court found that the qui tam provisions do not create a true agency relationship insofar as they confer upon the relator rights over and above those of the government, including the right to maintain a false claims suit in the face of governmental opposition. ${ }^{182}$ Because these features of the statutory regime take the FCA outside the concept of agency, the statute does not vest the relator with representational standing on an agency theory.

The Court's rejection of the agency theory in this context does not doom its viability in others; indeed, where a statutory regime does create a true agency relationship, the agency theory may have far greater potential than the assignment theory for representational standing and the reintegration of private litigants into public law litigation. In order to fully comprehend the contours of agency theory and its implications for public law, it is important to consider: (I) the constitutional limitations on the ability of Congress or the Executive to designate private citizens as agents authorized to vindicate governmental interests; (2) the contours of a true agency relationship in the public law context; and (3) the significance of the distinction between sovereign and proprietary interests in terms of what governmental interests an agent may vindicate.

180. See Vermont Agency of Natural Res. v. United States ex rel. Stevens, 120 S. Ct. 1858, 1862 (2000)

181. Id.

182. Id. The Court found, for exampie, that the qui tam provisions of the FCA give the relator "the right to continue as a party to the action," even where the Government has intervened to prosecute the claim, entitle the relator "to a hearing before the Government's voluntary dismissal of the suit," and prohibit the Government from "settling the suit over the relator's objections without a judicial determination" of the fairness of the proposed settlement. $I d$. 


\section{Constitutional Limitations on Agency in Public Law Enforcement}

Before considering the circumstances under which agency principles may properly apply in the public law context, it is first necessary to examine certain threshold constitutional limitations on the government's porver to authorize private agents to pursue governmental claims. The first question is whether the creation of an agency relationship to assert governmental claims impinges upon the Executive's duties under the Take Care Clause of Article II. The Court considered this precise question in Morrison v. Olson, ${ }^{183}$ which concerned the Article II implications of a statute authorizing the appointment of a private citizen as independent counsel to investigate high-ranking government officials suspected of wrong-doing. In particular, the Morrison Court considered whether the appointment of an independent counsel "impermissibly undermine[s]' the powers of the Executive Branch, or 'disrupts the proper balance between the coordinate branches [by] prevent[ing] the Executive Branch from accomplishing its constitutionally assigned functions." "184

In considering this question, the Court found that while it was "undeniable" that the statute "reduces the amount of control or supervision" exercised by the Executive over the "investigation and prosecution of a certain class of alleged criminal activity," $" 185$ the Executive nonetheless retained sufficient control over the independent counsel so as to discharge its duties under Article II. ${ }^{186}$ First, an independent counsel can only be appointed by specific request of the Attorney General. ${ }^{187}$ Thus the statute "gives the Executive a degree of control over the power to imitiate an investigation by the independent counsel."188 Second, once an independent counsel is appointed, he must abide by Justice Department policy and accept his jurisdiction as defined by the Attorney General. ${ }^{189}$ Finally, the Attorney General retains the power to remove the independent counsel for "good cause," a porver the Court found "provides the Executive with substantial ability to ensure that the laws are faithfully executed by an independent counsel." $" 190$

183. 487 U.S. 654 (1988). Morrison dealt with the independent counsel provision of the Ethics in Government Act. See id.

184. Id. at 695 (quoting Nixon v. Adm'r of Gen. Servs., 433 U.S. 425, 443 (1997)).

185. Id. For example, the Attorney General may not appoint the Independent Counsel of her choice and has limited powers of removal. Id. at 695-96.

186. Id. at 696. The Court found that the "Act does give the Attorney General several means of supervising or controlling the prosecutorial powers that may be wielded by an independent counsel." Id.

187. Id. The Attorney General's decision not to request appointinent if she finds "no reasonable grounds to believe that further investigation is warranted" is unreviewable. Id.

188. Id.

189. Id.

190. Id. 
The Morrison Court thus examined the three stages of executive involvement in the independent counsel process-initiating the action, conducting the litigation, and terminating the action--to determine whether the Executive retained sufficient control over the investigative and prosecutorial process for purposes of Article II. ${ }^{191}$ In the wake of Morrison, then, any Congressional conferral of power upon private citizens to pursue governmental claims under an agency theory must be analyzed with a view towards the retention of Executive control over critical stages of litigation brought on its behalf.

Another limitation on the ability of Congress to vest private actors with public enforcement power under an agency theory lies in the injuryin-fact requirement of the Court's Article III standing jurisprudence. As Stevens suggests, representational standing applies only where (1) the private citizen's "complaint asserts an injury to the United States,"192 and (2) the particular statutory regime at issue creates either a true assignment or a true agency relationship. ${ }^{193}$

The constitutional "injury-in-fact" requirement is not a significant limiting factor in the representational standing context because it will be satisfied so long as the government has suffered imjury in its proprietary or sovereign capacity. This is consistent with the concept of representational standing developed in Warth $v$. Seldin ${ }^{194}$ where the Court observed that a private organization has standing to bring suit as a representative of its members, even where it alleges no mjury to itself. ${ }^{195}$ As the Court noted in Warth, Article III will be satisfied in the representational standing context where the principal (or assignor, as the case may be) has suffered injury-mfact:

the possibility of such representational standing... does not eliminate or attenuate the constitutional requirement of a case or controversy. The association must allege that its members, or any one of them, are suffering immediate or threatened injury as a result of the challenged action of the sort that would make out a justiciable case had the members themselves brought suit. ${ }^{196}$

191. Id. at 650-51, 691-96.

192. Vermont Agency of Natural Res. v. United States ex rel. Stevens, 120 S. Ct. 1858,1862 (2000).

193. Id. at $1862-63$.

194. 422 U.S. 490, 511 (1975).

195. See, e.g., Don't Waste Ariz., Inc. v. McLane Foods, Inc., 950 F. Supp. 972 (D. Ariz. 1997) (discussing the elements of representational standing); 13 CharLes A. Wright ET AL., Federal Practice AND Procedure $§ 3531.9$ (2d ed. 1995 \& Supp. 1999) ("In a variety of circumstances, both traditional and modern, a party is permitted to appear in court as a formal representative of other interests. Trustees, guardians and personal representatives are familiar examples."); see also FED. $R$. Crv. P. 17(a) (allowing parties to sue "without joining the party for whose benefit the action is brought").

196. Warth, 422 U.S. at 511 (citations oinitted). 
A more significant limitation arising out of Article III lies in the requirement that the statutory regime at issue create a true agency relationship. Recall that in Stevens itself, the Court specifically found that the qui tam provisions of the FCA do not create a true agency relationship, and it therefore declined to recognize representational standing based on an agency theory. ${ }^{197}$ The question is, therefore, under what circumstances will legislation be found to create a true agency relationship such that the injury-im-fact of the principal (or government) may be conferred upon the agent (or private citizen)?

\section{The Contours of True Agency}

The Stevens Court found agency principles mapplicable to the FCA precisely because the statute vests relators with rights distinct from those of the principal. There is no doctrinal reason, however, to doubt that Congress may constitutionally confer private citizens with authority to bring suit on behalf of the government under an agency theory where the agent's authority is limited to that of the government. Put differently, a true agency relationship at public law requires that the private citizen-agent act only to promote the interests of the government-principal. ${ }^{198}$ Once agam, reference to traditional principal-agent doctrines developed im the private law context proves instructive.

An agent is generally defined as "one who acts for or in place of another by authority from him; a substitute, a deputy, appointed by principal with power to do the things which principal may do."199 Under traditional principal-agency law, an agent vested with authority to vindicate the interests of the principal is necessarily subject to the control of the principal, and her authority, therefore, may not conflict with or extend beyond that of the principal. ${ }^{200}$

In the private law context, the concern over granting agents broad discretion to vindicate the interests of the principal may be explained in terms of economics. A rational economic actor will not establish an agency relationship where the benefits to be gained are outweighed by agency compliance costs, including the costs of monitoring the agent, and the costs likely to be incurred as a result of agent self-dealing. ${ }^{201}$ The broader the

197. Stevens, 120 S. CT. AT 1862.

198. Nor can it be seriously doubted that the government may establish agency relationships with private citizens. See, e.g., Morrison v. Olson, 487 U.S. 654, (1988). The specific question addressed here is what limitations are required to ensure that such agency relationships pass constitutional muster.

199. Black's Law Dictionary 41 (6th ed. 1991); see also Restatement (SECOND) OF AgENCY $\S 1$ (1957) ("(1) Agency is the fiduciary relation which results from the manifestation of consent by one person to another that the other shall act on his behalf and subject to his control, and consent by the other so to act; (2) The one for whom action is to be taken is the principal; (3) The one who is to act is the agent.").

200. Restatement (SeCOND) OF AgENCY § 1 (1957).

201. According to one commentator, 
authority vested in the agent, the higher the likelihood that the agent will act without restraint ${ }^{202}$ and that her actions will diverge from the principal's best interests, thus increasing agency compliance costs. ${ }^{203}$ This cost-benefit calculus helps explain the common law rules limiting and defining the circumstances under which an agency relationship will be recognized.

Similarly, the creation of a true agency relationship in the public law context requires a statutory regime that (1) ensures the citizen-agent will act only to further the government's interests; and (2) subjects the actions of the citizen-agent to the control of the government-principal. ${ }^{204}$ As in the private law context, agency compliance costs ratchet upwards in direct correlation with the breadth of discretion vested in the agent. ${ }^{205}$ At some point, as in Stevens itself, the discretion vested in the private citizen is so broad, as where the citizen is furnished rights and incentives independent of the government, that the relationship is no longer recognizable as a true agency.

The costs of agency compliance, particularly the costs associated with the divergence of the agent's interests from those of the principal, will vary depending upon the nature of the interests at stake. It may well be, for example, that some areas of governmental activity implicate such high stakes that tolerance for the costs associated with divergence of interests, as

[a]gency costs are all the costs that arise where the agent acts, and the principal expects him to act, out of the agent's self-interest in the secure knowledge that: (1) the principal cannot be fully aware of everything that the agent does and fails to do; and (2) that the principal cannot make the agent pay the full cost of his failure to faithfully serve the principal. The central and most prominent agency cost is shirking, i.e., merely not being as attentive to one's task as one would if one were serving one's own interests rather than the principal's.

Lloyd R. Cohen, The Public Trust Doctrine: An Economic Perspective, 29 CAL. W. L. REv. 229, 265 (1993).

202. See, e.g., Mark A. Pollack, Delegation, Agency, and Agenda Setting in the European Community, 51 INT'L ORG. 99 (1997).

203. See Daryl Levinson, Making Government Pay: Markets, Politics, and the Allocation of Constitutional Costs, 67 U. CHI. L. REV. 345, 383 (2000) (noting that "[t]he extent to which agency actions are aligned with the preferences of their legislative and executive principals depends on how successful these principals are at inonitoring agencies to detect noncompliance").

204. See Daniel Meltzer, Congress, Courts and Constitutional Remedies, 86 Geo. L.J. 2537, 2552 (1998) (noting "that duties expressly imposed exclusively on a principal generally leave its agents free to act in violation of those duties, on the theory that any actions by the agents that would cause the principal to be in violation cannot be attributed to the principal").

205. Professor Levinson disagrees that private law agency principles can be used to accurately predict governmental behavior. See generally Levinson, supra note 203. h1 particular, Professor Levinson has argned that "certain characteristics of govemment bureaucracy may impede efforts to structure incentives by limiting the carrots and sticks" at the disposal of the government to control the actions of its agents. Id. at 385. Private principals, on the other hand, freely respond to market signals and "have far greater latitude to structure the incentives" of their agents. Id. These observations lead Professor Levinson to conclude that for government, significantly more so than for private firms, the behavior of agents may diverge from the policy preferences of high-level decision-maker principals. Id. But see Myriam Gilles, In Defense of Making Government Pay: The Deterrent Effect of Constitutional Tort Remedies, 35 GA. L. REV. (forthcoming 2001) (arguing that agency coinpliance costs are no greater in the public sector than in the private sector). 
between principal and agent, will approach zero. Therefore, in order to understand the limits on the application of agency principles to public law, it is important to consider the types of governmental interests an agent may be authorized to vindicate.

\section{The Sovereign vs. Proprietary Distinction Revisited}

Unlike assignment, which by its nature may provide a basis for representational standing only where the government's proprietary interests are at stake, ${ }^{206}$ agency principles may be employed to authorize private actors to pursue either the government's proprietary or sovereign imterests. ${ }^{207}$ In pursuit of its proprietary interests, the government may either assign a portion of its claims to a private citizen, as the Stevens Court recognized in the FCA context, ${ }^{208}$ or it may retain a private citizen as an agent by paying "a fee for prosecuting the action." ${ }^{209}$ In either event, compliance costs are relatively low where the government's proprietary interests are at stake, as these interests typically do not implicate core executive functions. It is enough, in the context of proprietary claims, that an assignment be a partial one, or that an agency relationship conform to the requirements of a true agency.

In pursuit of its sovereign interests, by contrast, the government must employ principles of agency rather than assignment. The agency concept alone is suited to the pursuit of sovereign interests, ${ }^{210}$ where there is no

206. Supra text accompanying notes 151-164 (discussing applicability of assignment theory of standing where the government suffers injury in its proprietary capacity).

207. The "sovereign" is the "supreme authority in the body politic," as exemplified by its control over "territory and the persons living there, immunity against challenges to authority, and legitimation of leadership." H. Jefferson Powell \& Benjamin J. Priester, Convenient Shorthand: The Supreme Court and the Language of State Sovereignty, 71 U. CoLo. L. REv. 645, 648 (2000). The sovereign draws its authority from the people, who ratify the government and legitimize the power of the sovereign: "[T]he people of a State may, by the form of government they adopt, confer on their public servants and representatives all the powers and rights of sovereignty which they themselves possess; or may restrict them within such limits as may be deemed best and safest for the public interest." Ohio Life Ins. \& Trust Co. v. DeBolt, 57 U.S. (16 How.) 416, 428-29 (1853); see also Chisolm v. Georgia, 2 U.S. 419 (2 Dall.) 454 (1798) ("[T]here is but one place where [the term 'sovereign'] could have been used with propriety-in conjunction with the term the 'people of the United States."').

It could also be argued that agents may be authorized to pursue quasi-sovereign interests, which "are not sovereign imterests, proprietary interests, or private interests pursued by the state as a nominal party," but consist instead of "a set of imterests that the State has in the well-being of its populace." Alfred L. Snapp \& Son, Inc. v. Puerto Rico, 458 U.S. 592, 602 (1982). For purposes of this discussion, however, the distinction between sovereign and quasi-sovereign interests is insignificant.

208. Supra text accompanying notes 165-180 (discussing the partial assignment of the government's proprietary claims to private citizens).

209. Vermont Agency of Natural Res. v. Umited States ex rel. Stevens, 120 S. Ct. 1858, 1861 (2000).

210. Considered in this hight, the agency theory articulated in Stevens may more precisely be termed a reverse-agency theory. As many scholars have asserted, the central idea of popular sovereignty is that "the people are the one and only sovereign in civil society," and the people may "cede governing authority to a constituted government," which is charged with the duty to pursue 
"recovery" to assign, and the available remedies are by their nature public, typically in the form of injunctive or declaratory relief, or damages which act essentially as fines payable to the federal treasury. ${ }^{211}$ The government's sovereign claims, brought to redress "injury ... arising from violation of [the government's] laws,"212 are analogous to private law claims that are "personal" and non-assignable. ${ }^{213}$

The vindication of sovereign interests represents the very core of Executive function. The costs of divergence of interest as between agent and principal are thus heightened in this arena, and the retention of ultimate control by the Executive rises to the level of constitutional imperative. ${ }^{214}$ Morrison gives vent to these concerns, mandating that the Executive must retain control over key stages of hitigation brought to vindicate its sovereign interest in the investigation and prosecution of high ranking federal officials. ${ }^{215}$ In this connection, it is imteresting to contrast the standing analysis in Stevens with the holding in Morrison: in upholding the relator's standing to pursue the government's proprietary claims as an assignee, the Court was not troubled by the fact that the requisites of the Morrison executive control test were not met. ${ }^{216}$ Were the action in Stevens

public-regarding policies. Carlos E. Gonzalez, Reinterpreting Statutory Interpretation, 74 N.C. L. REV. 585,636 (1996) ("[T]lie essence of popular sovereignty is a principal-agent relationship between a principal/people and their constituted agent/govemment, under which a sovereign people grant governing power and authority to a government that acts as a trustee over the people's sovereignty."); see also Richard Pierce, The Role of the Judiciary in Implementing an Agency Theory of Government, 64 N.Y.U. L. REv. 1239, 1239 (1989) ("The Constitution is premised on the belief that government should act as the agent of the people."). In Professor Akhil Amar's words, "[t]rue sovereignty reside[s] in the People themselves.... Government officials [are] 'representatives,' 'agents,' 'delegates,' 'deputies, and 'servants' of the People. ... As sovereign, the People need not wield day-to-day power themselves, but could act through agents on whom they conferred limited powers." Akhil R. Amar, Of Sovereignty and Federalism, 96 YALE L.J. 1425, 1466 (1987). Thus, the concept of government authorizing the People to act as agents is a reversal or reinvestment of the power ceded to the government by the People.

211. Federal law fines are paid to the federal treasury. See, e.g., United States Dep't of Energy v. Ohio, 503 U.S. 607, 613 n.l (1992); see also Elizabeth Kundinger Hocking, Federal Facility Violations of the Resource Conservation and Recovery Act and the Questionable Role of Sovereign Immunity, 5 ADMIN. L.J. 203, 213 (1991) (discussing the importance of the fines for purposes of deterrence and suggesting that "the value of fines lies in their motivational potential rather than the revenues they generate").

212. Stevens, $120 \mathrm{~S}$. Ct. at 1862.

213. Supra text accompanying notes $152-160$ (discussing the non-assignability of "personal" claims).

214. By contrast, the executive control test of Morrison arguably does not apply nis the proprietary context, thereby ameliorating the constitutional agency compliance concerns that are present where sovereign interests are in play. Supra text accompanying notes 169-176 (discussing the inapplicability of the Morrison executive control test in the enforcement of proprietary governmental interests).

215. Morrison v. Olson, 487 U.S. 654, 660-61, 691-96 (1988).

216. See Stevens, $120 \mathrm{~S}$. Ct. at $1865,1865 \mathrm{n} .8$. Argnably, a statutory regine might create a true agency relationship without satisfying the demanding dictates of Morrison. 1 would submit that sucl an agency relationship would be a sufficient basis for representational standing to pursue the government's proprietary interests, while it may not suffice where the government's sovereign interests are at stake. 
directed towards vindicating the government's sovereign interests, the Court would certainly have required that the Executive keep the relator on a shorter leash.

It therefore appears that representational standing to pursue the government's sovereign interests may be predicated upon agency where the agent's authority is strictly limited and conforms to the mandates of Morrison. ${ }^{217}$ Indeed, legislation which employs agency principles to support representational standing in the pursuit of sovereign interests holds great promise for the reintegration of private citizens into public law litigation. For the first time since Lyons, Lujan, and the full-scale constitutionalization of standing doctrine, Congress is free to capitalize on the resources of the citizenry, the milhons of "eyes on the ground," that drove the public law revolution of the latter half of the twentieth century.

\section{IV}

\section{IMPLiCATIONS AND ApPLications of RePresentational Standing}

In the wake of Stevens, legislators now have two portentous new standing theories upon which to draw in drafting legislation aimed at increasing and improving the private role in public law hitigation. In areas as diverse as environmental protection, police misconduct, tax collection, and civil forfeitures, the representational standing theories elucidated in Stevens provide a framework for private citizens and the government to work together at solving some of the nation's gravest social ills. ${ }^{218}$

The agency theory, in particular, holds promise for dramatically broadening the role of private actors in public law litigation. Armed with a proper understanding of the agency theory of representational standing, legislators now have the wherewithal, for the first time since the Court's restrictive standing jurisprudence reached its zemith in Lyons and Lujan, ${ }^{219}$ to resuscitate public law litigation by tapping the experiential, financial, and other resources of private individuals and associations that are willing and competent to tackle important public issues in the federal courts. In the wake of Lyons and Lujan, innumerable commentators have bemoaned the loss of the citizenry as a force in public law litigation. ${ }^{220}$ The agency theory

217. See supra text accompanying notes 183-197.

218. Private enforcement could be critical to achieving various civil and criminal law enforcement goals. See, e.g., Alyeska Pipeline Serv. Co. v. Wilderness Soc'y, 421 U.S. 240, 263 (1975) (acknowledging that, in many imstances, "Congress has opted to rely heavily on private enforcement to implement public policy"); see also S. REP. No. 94-1011, at 2, reprinted in 1976 U.S.C.C.A.N. 5908, (recognizing that "[a]ll of these civil rights laws depend heavily upon private enforcement").

219. See supra text accompanying notes 69-94 (discussing the constitutionalized standing rules applied in Lyons and Lujan).

220. See, e.g., Patti A. Meeks, Justice Scalia and the Demise of Environmental Law Standing, $8 \mathrm{~J}$. LAND UsE \& ENVTL. L. 343, 364 (1993) ("Scalia has apparently used Lujan as a stepping stone towards constitutionalizing the generalized grievance standing limitation."); Nichol, supra note 93, at 1167-68 (reasoning that Justice Scahia's approach to standing threatens plaintiffs' ability to bring 
of representational standing may allow these scholars to stop grieving and, instead, to begin contemplating imaginative applications for the agency theory of standing in a broad spectrum of areas of federal legislation.

The assignment theory, relating as it does to any area of federal law that implicates the government's proprietary interests, likewise holds promise in an era where "public-private" partnership has become a campaign slogan, 221 and where politicians feel pressed to fund governmental activities by means other than straight taxation. As discussed below, the potential implications of this theory for the collection of federal revenues are significant. Nevertheless, before rushing headlong through the opening created in Stevens, it is worth considering the potential secondary effects of any regime that would vest in private hands the power to use the federal courts in enforcing the federal laws.

\section{A. Potential Applications of the Assignment Theory}

The assignment theory of standing can be employed to provide incentives for private citizens to ferret out and prosecute the government's proprietary injuries in areas far beyond false claims. For example, Congress could include provisions in tax collection legislation, effecting partial assignments to private citizens of claims directed at the recovery of delinquent taxes, as well as in more exotic areas of the law, such as civil forfeiture.

\section{Delinquent Tax Collection Suits}

On this model, tax collection might be optimized by assignimg private citizens a portion of the delinquent taxes that they are able to recover for the government. ${ }^{222}$ One commentator has noted that, "[a]s financial burdens

\footnotetext{
"public law litigation" generally and "threatens to constitutionalize an unbalanced scheme of regulatory review"); Sunstein, supra note 10, at 166 (stating that Article III appears to forbid Congress from granting standing to "citizens" qua citizens); Keith Werhan, Delegalizing Administrative Law, 1996 U. ILL. L. REv. 423, 455 (1996) (noting that the Lujan Court constitutionalized the generalized grievanee principle and subjected statutory standing provisions to judicial review).

221. For example, in accepting their parties' nominations, both Al Gore and George W. Bush characterized private enterprise as the "engine" that runs the American economy and both "promised" to find new and creative ways for government to partner with the private sector to improve the delivery of serviees. David Corn, Down to the Wire, ThE Nation, Nov. 13, 2000.

222. Such provisions would resemble the medieval practice of "tax farming," whereby the king would "sell" to his subjects the right to collect traditional taxes. Typically, tax farmers were held liable for the total expected tax revenue, meaning that every dollar not collected was another dollar lost by the tax farmer. As a result, tax farmers often resorted to torture and terror to recover taxes, and the taxfarming system was abolished as bratal. See Frank S. Alexander, Tax Liens, Tax Sales and Due Process, 75 IND. L.J. 747, 751 (2000) (noting that the use of "private entities to assist in the collection of property taxes," represents "a return in some ways to the Roman era of 'tax farming' or the nineteenth-century reliance on 'tax ferrets' or 'tax scavengers"'); Adam Melita, Note, Much Ado About \$26 Million: Implications of Privatizing the Collection of Delinquent Federal Taxes, 16 VA. TAx. REv. 699, 701 (1997) (noting that under the tax-farming system, "the power to collect the taxes was implicitly assigned from the state to the tax farmer').
} 
on local governments increase, the fiscal impact of a $3 \%$, or $10 \%$, delinquency rate in tax collections becomes dramatic., ${ }^{9223}$ Not surprisingly, state and local governments have already begun to use private entities to assist in the collection of property taxes in an effort to improve tax collection. ${ }^{224}$ For example, some municipalities in Texas pay private lawyers contingent fees to collect taxes, ${ }^{225}$ and other jurisdictions use private bill collectors to collect taxes after the state has determined a tax is due. 226

Congress could include provisions in the tax code which assign to private citizens a percentage of delimquent taxes recovered; such provisions would enable assignees to bring actions to recover overdue taxes or force an audit to determine whether the tax is due. The legislation might be modeled on the qui tam provisions of the FCA, which would allow the Executive, through the Internal Revenue Service, to have the "first bite at the apple" in determining whether to pursue an action mitiated by a private citizen for collection of delinquent taxes. Alternatively, private firms may be contractually engaged as partial assignees to pursue these claims. Either way, where the Executive chooses to allow the private actor to prosecute the delinquency claim, the assignee would receive a portion of the recovery, and the remainder would go to the federal treasury. Such an assignment would supplement the ability of Internal Revenue Service to

223. Alexander, supra note 222, at 747.

224. For example, Mississippi, Vermont and Virginia have enacted legislation authorizing localities and municipalities to enlist the aid of private collection agencies or attorneys in tax collection efforts. See Miss. Code ANN. § 21-17-1 (1996); VT. StAT. ANN. tit. 13, § 5240(c) (1995); VA. CodE ANN. $\$ 19.2-349$ (B) (Michie 1996).

225. The Texas Property Code authorizes municipal taxing units to "contract with any competent attomey" to collect delimquent taxes and to pay the attomey "20 percent of the amount of delinquent tax, penalty, and interest collected." TEx. TAx CoDE ANN. \$ 6.30(c) (West 1997).

226. At the local level, private attomeys or bill collectors are generally not authorized to bring court actions on behalf of the government, or to force an audit to determine whether the tax is due. South Carolima, however, has proposed an ordinance that authorizes the bill collector association to assess the tax due, audit the tax, and bring an action "in the name of the Municipality without further approval by the Municipality." Municipal Association of South Carolina, Model Ordimance MASC-50, 98-002. The proposed ordinance provides, in relevant part, that the bill collector association is "designed as the exclusive agent of the Municipality for assessment and collection of the said business license taxes and penalties utilizing all procedures and actions authorized by ordinance or State law, and such procedures and actions may be invoked in the name of the Municipality without further approval by the Municipality." Id. The association retains $4 \%$ of all funds collected under this proposal. Id.; see also In re Phillip Morris U.S.A., 436 S.E.2d 828 (N.C. 1993) (upholding a statute that authorized a private party to receive a contingent fee of $35 \%$ of taxes discovered). But see Sears, Roebuck \& Co. v. Parsons, 401 S.E.2d 4, 5 (Ga. 1991) (finding a contingent fee contract void as against public policy, noting that "[f]aimess and impartiality are threatened where a private organization has a financial stake in the amount of tax [assessed]" and that "[t]he people's entitlement to fair and impartial tax assessments lies at the heart of our system, and, indeed, was a basic principle upon whicl this country was founded"). 
ferret out tax dodgers and would have the potential to add millions, or even billions, in revenues to the federal government. ${ }^{227}$

In the wake of Stevens, the constitutionality of such a regime appears beyond doubt. The authorizing legislation would effect a classic partial assignment of proprietary governmental claims. Separation of powers principles and Article II concerns are avoided because the assignment is a partial one. In addition, the Court's Article III standing jurisprudence poses no obstacles, because the government's injury-in-fact is transferred to the assignee, as in Stevens itself. ${ }^{228}$

To say that a statutory regime is constitutional, however, is not necessarily to say that it makes for sound public policy. Legislation authorizing private citizens to assist the government in the recovery of delinquent debt may have troubling implications. ${ }^{229}$ For example, one might reasonably fear that such a regime would amplify the power of "Big Brother" by einpowering a million "little brothers" to pry into private inatters and generate an atmosphere of societal mistrust. Clearly, in considering any such legislation, prudent lawmakers would want to study potential safeguards, such as governmental vetting procedures ${ }^{230}$ and cost-shifting provisions..$^{231}$

227. Congress has tried, but thus far failed, to create such an assignment for the collection of delinquent taxes. In 1996, Congress approved an IRS budget which included \$13 million dollars for a special pilot program designed to award contracts to private law firms and debt collection agencies to collect delinquent taxes. Treasury, Postal Service, and General Government Appropriations Act of 1996, Pub. L. No. 104-52, 109 Stat. 468, 473-74. In 1997, funding for the program was doubled to $\$ 26$ million in the 1997 Omnibus Consolidated Appropriations Act, Pub. L. No. 104-208, 110 Stat. 3009. However, the pilot program fails to create an assignment for two reasons. First, the program operates on a flat fee structure rather than a percentage of the recovery. See Herman P. Ayayo, ABA Tax Section Meeting, As Richardson Heads to Exit, ABA Considers IRS Restructuring, 74 TAx Notes 266, 266 (1997). In other words, collectors are paid a flat fee for collecting delinquent taxes, without regard to the amount of the delinquency. In order to create a true assignment, collectors would have to be paid a percentage of any successful recovery of delinquent taxes. Second, private collectors are only permitted to contact the taxpayer regarding the delinquency and to notify the taxpayer of repayment options; collectors have no enforcement authority, but may only refer the debtor back to the IRS. So, rather than let private collectors "run with the ball" after failed IRS attempts to collect the delinquent tax, the program keeps the collectors on a short leash; indeed, they are not "collectors" at all, since any substantive processing requires IRS intervention. See Melita, supra note 222, at 700.

228. So, for example, if Congress were to assign private citizens a portion of tax delinquencies successfully recovered, one might argue that this would violate the Court's prohibition on taxpayer standing. See, e.g., Frothingham v. Mellon, 262 U.S. 447 (1923). However, an assignee bringing an action to recover taxes due to the government need not rely on his status as a taxpayer, but rather, need only point to the government's proprietary injury as the basis for his standing to bring suit.

229. See Melita, supra note 222, at 721-26 (discussing potential implications of privatizing tax collection, including the violation of taxpayers' rights and taxpayers' privacy, and the diminishment of confidence in the IRS).

230. See Gilles, supra note 2 (describing the Justice Department's initial review of qui tam actions as serving a vital quality control function).

231. For example, legislators might consider provisions requiring assignees who bring frivolous or harassing litigation to pay all costs and attorney's fees. 


\section{Civil Forfeiture Actions}

The application of the assignment theory in the civil forfeiture context may create another fairly troubling scenario. ${ }^{232}$ The Supreme Court has held that civil forfeitures of drug related assets are in fact remedial, and not punitive, measures insofar as they seek to compensate the government for the costs of its war on drugs. ${ }^{233}$ The government, according to this legal fiction, is acting in its proprietary capacity, seeking the recovery of lost assets. As a result, there is no constitutional impediment under current law to legislation assigning to private citizens a portion of the government's claim to drug-related assets.

The policy implications of permitting the assignment of civil forfeiture claims to private actors are nonetheless disturbing. One might well question whether the government ought to provide monetary incentives to individuals likely to have information concerning the proceeds of narcotics activity, as such a regime would likely attract imdividuals who are theinselves involved in drug trafficking. And even where the putative assignee is not involved with criminal activity, the extension of the assignment theory into the criminal realin invites a form of vigilantism that might well outweigh the benefits to the federal treasury. ${ }^{234}$

232. The Comprehensive Drug Abuse Prevention and Control Act of 1970, 21 U.S.C. $\S 881$ (1994), authorizes the forfeiture of the "illegal substance involved in the commission of an offense and all instrumentalities used in the manufacturing and distribution of the illegal substance." In 1978, the Act was amended to provide for the forfeiture of all the proceeds from an illegal drug transaction, and provided for an innocent owner defense. Pub. L. No. 95-633, 92 Stat. 3786, Title III; see also Eric Blumenson \& Eva Nilsen, Policing for Profit: The Drug War's Hidden Economic Agenda, 65 U. CHr. L. REv. 35 (1998) (discussing the development of civil forfeiture and asset distribution statutes aimed at deterring drug trafficking).

233. While the Court ruled in United States v. Austin, 509 U.S. 602, 619 (1993), that the Excessive Fimes Clause governs certain federal civil forfeiture proceedings because they are, at least in part, punitive, it appeared to overnule this aspect of Austin in United States v. Ursery, 518 U.S. 267 (1996). In Ursery, the Court found that Austin's line of reasoning defined "punitive" only for purposes of the Eighth Amendinent's Excessive Fines Clause, but not for purposes of the Fifth Amendment's Double Jeopardy Clause. Id. at 286-88. Thus, the Ursery majority concluded that in rem civil forfeitures are not punitive for purposes of Double Jeopardy.

234. Indeed, the current civil forfeiture regime is itself problematic. The federal civil forfeiture statute, 21 U.S.C. $§ 881$ (1994), allows agencies who seize drug-related assets to benefit directly from the forfeitures. When the govemment sells forfeited property, cash from the sale goes directly to the federal agency involved. That agency can, in turn, give part of the funds to state or local police in retum for their help; in this way, forfeited property pays for law enforcement, as Congress intended. However, such a powerful financial incentive may have some unintended consequences. The federal govemment can "adopt" seizures performed by a nonfederal agency when the criminal conduct violated federal law and then kick back up to 80 percent of the seized assets to that agency. See Directive 90-5, The Attorney-General's Guidelines on Seized and Forfeited Property (July 1990), in DEPARTMENT OF Justice Asset Forfeiture Manual B-541, B-545 (Prentice Hall 1994). Because this is far more than state agencies get using most state forfeiture statutes, state and local authorities have the incentive to complete a case, then federalize it to get a greater share of the money. This can be a large share indeed; local police departments can eam as much as 10 times their annual budgets by participating in a single operation. See Steve Stecklow, Big Money for a Tiny Police Force, PHILA. InQ., Aug. 24, 1992, at A1. 
While the application of the assignment theory of standing is necessarily limited to areas in which the federal government's proprietary interests are at stake, it is possible to imagine the usefulness of such a theory beyond false claims. Taxation and civil forfeitures provide soine msight, however, into the importance of carefully calibrating the social costs and benefits of applying the assignment theory. Nevertheless, these examples also make clear that the potential limitations of this theory for the collection of federal revenues are significant, and that further investigation is clearly warranted.

\section{B. Potential Applications of the Agency Theory}

The agency theory has potentially far broader application than the assignment theory, if only because the government suffers sovereign injury in many more diverse ways than it suffers proprietary injury. However, legislation seeking to predicate representational standing upon an agency theory requires careful drafting to ensure constitutional operation. In particular, it requires the establishment of a true agency relationship and a careful balancing of the constitutional imperative that the Executive retain ultimate control of the litigation against the prudential imperative that citizen-agents be vested with sufficient discretion to allow the legislative regime to achieve its intended purpose.

\section{Environmental Citizen Suits}

An instructive illustration lies in the citizen suit provisions of the federal environmental laws, ${ }^{235}$ which fail to establish the sort of true agency relationship required for the conferral of representational standing and,

Most disturbingly, this system creates a powerful incentive for police to refrain from killing the goose that lays the golden egg, and to leech off the drug trade that now constitutes their primary funding. See generally Blumenson \& Nilsen, supra note 232. For example, many police departments now favor the reverse-sting operation, an operation in which police pose as dealers to nab potential drug buyers, allegedly because it allows police "to gauge potential profit before investing a great deal of time and effort." J. Mitchell Miller \& Lance H. Selva, Drug Enforcement's Double-Edged Sword: An Assessment of Asset Forfeiture Programs, 11 JusT. Q. 313, 319 (1992). This kind of operation allows police to go after a buyer's valuable bankroll and car rather than a dealer's less valuable supply of drugs. Criminal defendants high in their organization's chain of command often have more assets to forfeit and can trade these in a civil case for leniency in the criminal one. Thus, the drug boss goes free, while the street-level dealer goes to prison.

Given the problems and conflicts inherent in the current civil forfeiture regime, it may be difficult to justify authorizing private citizens to "rat" on one another for a piece of a drug-related pie already being divided by hungry federal and state law enforcement agencies.

235. See Fletcher, supra note 15, at 233 (arguing that the Article 111 limitations on congressional grants of standing "limit the power of Congress to define and protect against certain kinds of injury that the Court thinks it improper to protect against"); Harold Krent \& Ethan Shenkman, Of Citizen Suits and Citizen Sunstein, 91 Mich. L. Rev. 1793, 1806-08 (1993) (explaining that just as Congress cannot delegate authority to individuals to regulate work place safety, it cannot confer upon private citizens standing to enforce statutes through citizen suit provisions); Sunstein, supra note 10, at 166 (stating that Article III appears to forbid Congress from granting standing to "citizens" qua citizens). 
thus, are plagued by latent constitutional infirmities requiring case-by-case determination under the constitutionalized standing inquiry. ${ }^{236}$ Citizen suit provisions allow private citizens to bring suit against violators of environmental laws, as well as against the regulatory agencies charged with environmental protection. ${ }^{237}$ Available remedies include civil fines, injunctions, and declaratory judgments, with all penalties and damage awards going to the federal fisc; the citizen suit plaintiff recovers only attorney's fees and costs..$^{238}$

By purporting to grant a private right of action to "persons having an interest which is or may be adversely affected" by polluting activity, ${ }^{239}$ the citizen suit provisions betray a measure of schizophrenia. On the one hand, the provisions are clearly intended to empower "private attorneys general"240 to enforce broadly held rights and to assert generalized grievances. Those persons who suffer direct environmental injury may seek compensation under state tort law or other legislation, ${ }^{241}$ whereas the citizen suit provision is for persons without compensable claims. On the other hand, as the Court's recent derrials of standing to citizen suit plaintiffs

236. See, e.g., Steel Co. v. Citizens for a Better Env't, 523 U.S. 83 (1998); Lujan v. Defenders of Wildlife, 504 U.S. 555 (1992).

237. Environmental citizen suit provisions generally authorize any "citizen," defined as "a person or persons having an interest which is or may be adversely affected," to commence suit to enforce statutory requirements against violators, or to require the government to perform a mandatory duty under the statute. Citizen suit provisions were first included in the Clear Air Act Section 304, 42 U.S.C. $\S 7604$ (1994). For a comprehensive listing of environmental citizen suit provisions, see Sunstein, supra note 10, at $165 \mathrm{n} .11$. "Person" is defined quite broadly in most citizen suit provisions. For example, the Clean Water Act definition of person includes "an individual, corporation, partnership, association, State, municipality, commission, or political subdivision of a State, or any interstate body." Federal Water Pollution Control Act § 502(5), 33 U.S.C. § 1362(5) (1994). These provisions confer jurisdiction on the district courts to entertain citizen suits without regard to diversity of citizenship or the amount in controversy. No citizen suit may be commenced unless sixty-days notice has been given to the violator, EPA, and other appropriate authorities, or where the EPA has commenced and is diligently prosecuting its own enforcement action. See, e.g., 33 U.S.C. $\$ 1365(b)(1)(A)$, (B).

238. See, e.g., Clean Water Act, 33 U.S.C. § 1365(d); see also Michael D. Axline, ENVIRONMENTAL CITIZEN SUTTS $\$ 2.08$, at 2-19 (1992).

239. E.g., 33 U.S.C. $\$ 1365 ; 42$ U.S.C. $\$ 7604$.

240. E.g., Natalie Bussan, All Bark and No Bite: Citizen Suits After Steel Company v. CBE, 6 Wis. ENvTL. L. J. 195 (1999) ("The townspeople have also been enlisted to enforce environmental laws. The environmental problems of the United States reached a crisis point in the early 1970's, and the Environmental Protection Agency didn't have enough 'marshals' to effectively enforce new environmental statutes. As a result, Congress enacted citizen suit provisions that 'deputized' citizens to bring suits against alleged violators to give bite to these new laws. The 'possies' [sic] Congress created are known as private attomey generals.").

241. The common law allows private individuals who suffer special damages to bring public nuisance actions. See John E. Bryson \& Angus Macbeth, Public Nuisance, The Restatement (Second) of Torts, and Environmental Law, 2 EcologY L.Q. 241, 250-51 (1972); see also Taylor v. City of Cincinnati, 55 N.E.2d 724, 727-32 (Ohio 1944) (noting that water pollution is an absolute nuisance); Kepler v. Indus. Disposal Co., 85 N.E.2d 308, 310 (Ohio Ct. App. 1948) (holding that air pollution is an actionable nuisance based on injury alone). 
show, ${ }^{242}$ the language of the provisions invites an inquiry into whether the individual "person[] having an interest" has herself suffered a concrete, particularized injury-in-fact. As a result, the current statutory regime has produced a predictably bizarre body of case law concerned with such issues as the circumstances under which a plaintiff's "aesthetic interest" in observing a species of crocodile may rise to the level of cognizable rights protected by Article III. ${ }^{243}$

One prescription for curing these infirmities in citizen suits would be to rely on the agency theory of representational standing. Congress could amend the provisions to provide expressly that citizen suit plaintiffs inay bring suit to vindicate injury suffered by the government in its sovereign capacity. Far from being an "end-run" around the Court's constitutionalized standing rules, such an amendınent would give vent to the true animating forces that underlie the citizen suit provisions, the empowerinent of private actors to enforce public environmental laws. ${ }^{244}$

Beyond merely affirming that citizen suits vindicate sovereign interests, however, any legislation designed to place the citizen suit provisions within the representational standing mold would have to create a true agency relationship where none currently exists. To be sure, the current citizen suit scheme does share many of the characteristics of a true agency: damages go to the federal treasury, ${ }^{245}$ plaintiffs receive only a "fee" for prosecuting the action, ${ }^{246}$ and the real rights being vindicated are

242. See supra text accompanying notes $67-98$ (discussing the constitutionalization of standing doctrine in cases such as Lujan and the impact of these heightened requirements on public law litigation); see also Nichol, supra note 93, at 1167-68 (reasoning that Justice Scalia's approach to standing threatens plaintiffs' ability to bring "public law litigation" generally and "threatens to constitutionalize an unbalanced scheme of regulatory review").

243. See, e.g., Lujan v. Defenders of Wildlife, 504 U.S. 555, 568 (1992); see also Wald, supra note 95 , at 239.

244. A House Report stated:

The argument that citizens' suits would interfere with an energetic and well organized cleanup program simply is not supported by the facts. A recent comprehensive study of citizens' suits brought under the major federal environmental laws which was conducted by the Environmental Law Institute at the request of EPA conclusively refutes the argument that such suits interfere with the agency's effective implementation of its statutory mandate. The study found that the nnmber of citizens' suits filed under major national environmental laws increased in direct response to a decline in EPA's enforeement activities following massive cuts in the agency's budget during the early eighties. The study further found that such suits fulfilled Congressional intent in enacting such provisions by serving as both a goad and an alternative to the agency's own inadequate enforcement efforts. The study dismissed all allegations that such suits interfere with government enforcement programs or are brought against insignificant violators of the law. Finally, the study indicated that the possibility of citizens' suits gives industry an added incentive to comply with the law.

H.R. REP. No. 99-253, pt. I, at 289-90 (1985), reprinted in 1986 U.S.C.C.A.N. 2835, 2964-65.

245. See Jeffrey G. Miller, Private Enforcement of Federal Pollution Control Laws, 13 ENVTL. L. REP. 10, 310 (1983) (noting that citizens have not been allowed to sue for personal damages, but only to redress statutory violations).

246. Actually, the attorneys reprcsenting citizen suit plaintiffs receive the fee. First introduced in the Clean Air Act, attorney's fee provisions are now included in virtually all environmental legislation. As some commentators have argued, attorney's fees are vital to the citizen suit structure because of the 
those belonging to the public at large. ${ }^{247}$ However, the citizen suit provisions, as currently constructed, fail the test of a true agency on two counts.

First, the authority of citizen suit plaintiffs is not limited to serving the interests of the government; indeed, the provisions allow private litigants to sue the government itself. Under traditional doctrine, the agency relationship is destroyed, in its intended purpose, when the agent sues the principal. ${ }^{248}$ In the public law context, the ability of citizen suit litigants to bring actions against the EPA or other governmental entities dooms the applicability of the agency theory. Second, the agency theory requires that the government retain control over key aspects of litigation brought to vindicate its sovereign interests. ${ }^{249}$ Citizen suit litigation, as it currently exists, allows no such control, as plaintiffs may bring actions with which the Executive disagrees or which are inconsistent with national environmental protection strategies. ${ }^{250}$

Congress could, however, anend citizen suit provisions to effect a true agency relationship by (1) limiting the authority of citizen suit plaintiffs; ${ }^{251}$ and (2) prohibiting these citizens from suing the government or its administrative agencies. Such amendments may, however, carry sigmificant costs that must be carefully weighed agaimst the potential benefits of broadening representational standing.

First, im limiting the authority of citizen suit plaintiffs, legislators would have to consider the relative burdens placed on the EPA. On the one

high costs associated with litigation. See, e.g., Mrchael D. AXuINE, ENvIRonMenTaL CITIZEN SuITs $\S$ 8.03, 8-2 (1995).

247. See, e.g., Frank Grad, Environmental Litigation and Some of its Ethical Problems, SE-55 ABA-ALI (noting that environmental citizen suit plaintiffs "carry very substantial responsibilities to the public, and overwhelmingly they represent major aspects of the public interest").

248. See, e.g., Bostrom v. Jennings, 40 N.W.2d 97, 102 (Mich. 1949) ("[W]hile the negligence of the agent is imputable to the principal making him liable to third parties, it is not imputable to him so as to bar his right to recover from the agent what he has been required to pay as compensation to such third parties."); see also John C. Coffee, Jr., Litigation and Corporate Governance: An Essay on Steering Between Scylla and Charybdis, 52 GEO. WASH. L. Rev. 789, 805 (1984) (discussing the effects, in the corporate context, of a corporation insuring itself against loss due to the negligent acts or omissions of its agents, rather than using the circular procedure of insuring its agents and then suing them for damages that only the insurance policy it purchased can cover).

249. See supra text accompanying notes 183-191 (discussing the implications of the Morrison executive control test on representational standing based on agency theory).

250. Currently, the federal executive appears relatively supportive of the citizen suit structure so long as it retains control over these private litigants. For example, im its amicus brief in support of citizen suit standing in Friends of the Earth v. Laidlaw, 120 S. Ct. 693 (2000), the government pointed out to the Court that, in those situations where the Executive Branch opposes a particular citizen suit, the citizen suit provisions allow the Administrator of the EPA to "intervene as a matter of right" and bring the Government's views to the attention of the court. Id. at 708 n.4.

251. One way in which the citizen-plaintiff's authority may be limited, so as to confonn to the constitutional dictates of the agency model, would be to provide the EPA the authority to deny private actors the right to bring a citizen suit, where the agency determines that such a suit is not in the government's best interests, along with the authority to intervene in any such litigation for the purpose of dismissing or settling the action. Gilles, supra note 2, at 1423. 
hand, the constitutional imperatives of the agency theory would require the EPA to triage all citizen suit complaints to determine whether these litigants are bringing suit to advance the sovereign interests of the government. ${ }^{252}$ The EPA would also be required to continue to exercise sufficient control over the conduct of the ensuing litigation. ${ }^{253}$ On the other hand, the enforcement burdens currently borne by the EPA would be significantly lightened by allowing private citizens and organizations to "take the laboring oar" in prosecuting actions against private violators.

Second, an amendment which prohibits citizens from suing the government for environmental violations or the failure to promulgate regulations would likewise require consideration of the relative costs and benefits. On the one hand, such an amendment would enable representational standing based upon the agency theory, resulting in fewer denials of citizen suit standing and more effective inclusion of private citizens in environmental enforcement efforts. On the other hand, Congress nuay determine that a prohibition upon citizen suits against the government would be "throwing the baby out with the bath water," to the extent that the beneficial impact of suits against the EPA outweighs the narginal increase in enforcement efforts against private polluters that would result from granting private citizens representational standing under the agency theory. ${ }^{254}$

In the end, a representational standing-based regime provides a potentially attractive alternative to the problem-ridden citizen suit provisions.

\section{Police Misconduct Litigation}

The agency theory of representational standing may also be applied to reintegrate private citizens in the government's efforts to reduce instances of police misconduct. Recall that, under the equitable standing bar of Lyons, victims of police brutality must show to a "substantial certainty" that they themselves will suffer future injury in order to establish standimg

252. While the EPA is currently authorized to review citizen suits to determine whether it should intervene in the action, the implementation of the agency theory of representational standing would arguably require a more searehing review into the interests to be vindicated by any proposed citizen suit action.

253. See supra text accompanying notes 169-176 (discussing the Morrison test of "executive control").

254. This latter objection is suspect where citizen suits against the federal government allege a failure to enforce regulations against private (or state and local) entities. To the extent we are concemed with beefing up enforcement efforts against private entities, one might well argue that the resources of citizen-plaintiffs are more efficiently employed in suing the polluter, rather than hounding the overworked government agency charged with enforcement. If that is true, then the only values in retaining a private right of action against the government itself are (1) to restrain federal activities that adversely affect the environment; and (2) to ensure that the agency pronulgates rcgulations in accordance with Congressional mandates. And there is no reason why those private rights of action could not be retaiued, wholly separate and apart froin legislation that provides for representational standing to sue private (or state or local) entities on an agency theory. 
to enjoin ongoing unconstitutional police practices. ${ }^{255}$ Because this equitable standing doctrine is rooted in the Constitution, Congress is powerless to vest private citizens with authority to seek forward-looking relief against offending law enforcement organizations. Indeed, the most Congress could do in the wake of Lyons was to enact a statute, 42 U.S.C. Section 14141, which empowers the Attorney General to uncover and sue to enjoin unconstitutional police "patterns and practices."256 The victims of police misconduct and community leaders are thus left on the legal sidelines, relegated to approaching the U.S. Department of Justice, hat in hand, and requesting that federal officials bring actions against pohce departments engaged in unconstitutional "patterns and practices."

Six years after its imception, it is fair to say Section 14141 has proven ineffective, as the government has failed to muster the political will or requisite resources to address systemic pohice misconduct in a meaningful way. ${ }^{257}$ As I have argued elsewhere, Congress may overcome both the ineffectiveness of the current Section 14141 regime and the equitable standing bar of Lyons by creating true agency relationships with private citizens, which I termed "deputations" prior to Stevens, ${ }^{258}$ to aid the government in its efforts to enjoin unconstitutional pohice practices. Specifically, Congress could amend Section 14141 to add a provision which allows the Justice Department, in appropriate circumstances, to authorize private citizens to bring suits for injunctive relief against

255. Supra text accompanying notes 69-82 (discussiug the equitable standing bar announced in Lyons).

256. 42 U.S.C. $\$ 14141$ (1994).

257. One measure of the ineffectiveness of the statute is the number of suits brought by the Justice Department to reform police "patterns or practices." While the Justice Department las purportedly investigated dozens of police departments over the past six years, it has only filed suit against three. The suits were brought against the Pittsburgh, Pennsylvania, Steubenville, Ohio and Columbus, Ohio police departments. See United States v. City of Pittsburgh, No. 97-0354 (W.D. Pa. consent decree entered Apr. 16, 1997); United States v. City of Steubenville, No. C2-97-966 (S.D. Ohio consent decree entered Sept. 3, 1997); Mark Ferenchik \& Doug Caruso, Coleman Listens to Protesters' Concerns, Columbus Dispatch, Mar. 22, 2000, at 8E (reporting that the Justice Department has sued the Columbus Police Department over alleged civil rights abuses). Oddly, larger urban police departments with long histories of police problems have seemingly escaped federal intervention under Section 14141. This led Steubenville City Manager Gary Dufor to remark: 'We're an awfully small community. You see all these problems that have come up at the police departments in Los Angeles and New York and New Orleans, and you've got to wonder, why us?" Eric Lichtblau, U.S. Low Profile in Big-City Police Probes Is Undcr Fire: Law Critics Say Justice Dept. Boldly Pursues Misconduct Cases in Smaller Towns But Goes Slow on Larger Inquiries, L.A. Times, Mar. 17, 2000, at A1 ("Indeed, while federal officials... have stepped up their four-year inquiry into broad patterns of misconduct at the Los Angeles Police Department, critics are left to wonder how the Justice Department missed warning signals leading up to the worst corruption scandal in LAPD history. And they question whether federal authorities have the resources-or the will-to nove aggressively now in cleaning up the embattled foree.").

258. Gilles, supra note 2, at 1384, 1388. 
unconstitutional police "patterns or practices" where the government, for whatever reason, declines to do so itself. ${ }^{259}$

Such an amendment would conform to the constitutional mandates of the representational standing doctrine so long as the authority of private citizen-agents to bring "pattern or practice" suits is subject to executive control. In particular, on a model I have suggested, victims of unconstitutional police "patterns or practices"260 could file a petition with the Justice Department, seeking authority to bring a Section 14141 suit on behalf of the government to vindicate the sovereign injury to the government. ${ }^{261}$ After investigating the underlying allegations in the petition, the Justice Department could decide to (1) bring a Section 14141 injunctive action against the offending police department; ${ }^{262}$ (2) authorize the private citizen-agent to prosecute the Section 14141 action, subject to the Executive's right to intervene and assume control of the action at any point; or (3) quash the petition, thereby denying the private citizen the authority to bring the action. ${ }^{263}$ This scheme clearly retains the executive control demanded by Article II and separation of powers doctrine, while satisfying the demands of Article III by establishing a true agency relationship whereby the citizen-agent is authorized to vindicate the injury-in-fact suffered by the government in its sovereign capacity.

There are also, in my view, strong policy reasons for creating these sorts of agency relationships with private actors. As in so many other areas of the law, the government's enforcement efforts in the police misconduct

259. Id. at 36-37.

260. My model envisions that only actual victims of an unconstitutional police pattern or practice could petition the government. In other words, third parties and other concerned but uninjured citizens would not have a right to seek relief under this proposal. This parallels the requirement $\mathrm{m}$ qui tam provisions of the FCA which authorize only those individuals with "independent and original knowledge" of the alleged fraud to bring suit. 31 U.S.C. $\$ 3730$ (c) (3) (1) (1994). There is also an apt analogy in citizen suit provisions which authorize any "aggrieved person" to bring suit to remedy environmental injuries. See, e.g., Clean Air Act $\S 304,42$ U.S.C. $\$ 7604$ (1994).

261. Gilles, supra note 2, at 1417 (noting that "alleged victims of an unconstitutional police practice would file a petition with the Justice Department setting out the basis for their claims, alleging facts indicating the existence of an unconstitutional 'pattern or practice,' and delineating other damages claims under, for example, 42 U.S.C. $\left.\$ 1983^{\prime \prime}\right)$.

262. In this scenario, the case would proceed in a fashion similar to cases brought in Pittsburgh and Steubenville, with federal officials negotiating with or litigating against particular pohice departments and municipalities to identify and remedy unconstitutional "patterns or practices." See supra note 257 (discussing the "pattern or practice" cases brought by the Justice Department against Pittsburgh and Steubenville police departments).

263. In this scenario, the victim of the allegedly unconstitutional police practice could go forward with any private civil suit for damages, but would have no right to seek injunctive relief. Neither would the private petitioner have a right to seek judicial review of the Justice Department's election to quash the petition. While this would result in a completely insulated and unaccountable decision-making process, it is likely that in at least some high-profile cases, sufficient inedia and public attention would attend Justice Department decisions to quash. Public attention in these cases would likely "open up" the decision-making processes. 
field are hampered by budgetary and political obstacles. ${ }^{264} \mathrm{~A}$ regime of plaintiff-driven reform transcends governmental budgetary limitations by tapping the immense resources of the public at large, or, more accurately, those members of the public most affected by unconstitutional patterns and practices, and the community-based groups that represent their interests. Relatedly, the massive governmental expenditures required to detect and investigate misconduct are no match for the millions of "eyes on the ground" that bear witness to constitutional violations. And of course, private litigants are generally impervious to the political constraints that have impeded the meaningful enforcement of Section $14141 .^{265}$

\section{ConCLUSION}

Justice Scalia's discussion of Article III standing in Vermont Agency of Natural Resources $v$. United States ex rel. Stevens paves the way for nothing less than a wholesale revival of public law litigation. As this Article demonstrates, the theory of "representational standing" announced in Stevens provides legislators with a blueprint for constitutionally vesting in private citizens the authority to vindicate important public interests in the federal courts. While Congress has often expressed great interest in tapping private resources to aid in the enforcenent of public laws, in, for example, enacting citizen suit provisions of federal environmental statutes and other "private attorneys general" legislation, its efforts up to this point have been hindered by the Court's restrictive constitutionalized standing doctrine. Armed with the knowledge gleaned from Stevens, lowever, legislators may now consider the creation of partial assignments or true agency relationships between the Executive charged with enforcing its laws, and the individuals and community groups that are directly affected by these laws. Through wide application of the agency theory of representational standing articulated in Stevens, the government may be able to tap the private resources, personal experiences, and community-based incentives that have engineered the great reform movements of our time, and which have lain dormant in the wake of the Supreme Court's constitntionalized standing doctrine. Under this portentous theory of representational standing, public law litigation may yet have a future in keeping with its storied past.

264. Gilles, supra note 2, at 1408-12 (discussing the resource and political inpediments to effective DOJ einployment of Section 14141).

265. Political considerations in this particular area include the fear of alienating local law enforcement agencies and the reluctance of federal law enforcement officials to prosecute their municipal brethren. Private litigants are not hamstrung by these concerns. See Gillcs, supra note 2, at 1410-11. 
